\title{
SUMBER DAYA IKAN KARANG PERAIRAN KABUPATEN BANGGAI, SULAWESI TENGAH
}

\author{
Guridno Bintar Saputro') dan Isa Nagib Edrus²) \\ 1) Peneliti pada INSDAL Bakosurtanal, Cibinong-Bogor \\ 2) Peneliti pada Balai Riset Perikanan Laut, Muara Baru-Jakarta \\ Teregristrasi I tanggal: 25 September 2006; Diterima setelah perbaikan tanggal: 7Juni 2007; \\ Disetujui terbit tanggal 3 Maret 2008
}

\begin{abstract}
ABSTRAK
Penelitian ini dilakukan pada bulan Juli 2006 di perairan Kabupaten Banggai, Sulawesi Tengah. Tujuan penelitian adalah untuk mengidentifikasi indeks keanekaragaman sumber daya ikan karang yang terdiri atas kekayaan jenis, keanekaragaman jenis, dominasi jenis, keanekaragaman jumlah, dan keseragaman dalam komunitas. Metode yang digunakan adalah rapid reef assessment, line intercept transect, dan sensus visual. Penelitian ini, baik melalui proses rapid reef assessment maupun line intercept transect, berhasil mengidentifikasi 319 jenis ikan karang dan 121 marga dari 40 suku, dengan variasi antara lokasi berkisar antara 14 sampai dengan 140 jenis ikan karang. Jumlah wilayah transek 32 lokasi dan 6 lokasi antara lain memiliki indeks keanekaragaman ikan karang dengan kategori tinggi, 3 lokasi memiliki indeks keanekaragaman rendah, dan sisa 23 lokasi memiliki keanekaragaman ikan karang dengan kategori sedang.
\end{abstract}

KATAKUNCI: $\quad$ ikan karang, keanekaragaman, Kabupaten Banggai, Sulawesi Tengah

ABSTRACT: Reef-fish resources in the waters of Banggai Country, Central Sulawesi. By: Guridno Bintar Saputro and Isa Nagib Edrus

This study was carried out in July 2006 at the waters of Banggai District, Central Sulawesi with aim to identify the diversity indeces of reef fish resources including species richness, species diversity, species domination, diversity numbers, and evenness in fish community. Methods used were rapid reef assessment, line intercept transect, and visual census. The study of using both rapid reef assessment and line intercept transect identified successfully 319 species, 121 genus, and 40 families with reef fish species locally varied from 14 to 140. Total of transect areas were 32 sites and 6 of those were classified in the high diversity, 3 sites were classified the lower diversity and the others were grouped in the fair diversity.

\section{KEYWORDS: $\quad$ reef fishes, biodiversity, Banggai District, Central Sulawesi}

\section{PENDAHULUAN}

Terumbu karang adalah habitat ikan dan non ikan yang bernilai dalam kaitannya dengan tinggi keanekaragaman, di mana sumber daya ini mampu menyediakan sumber-sumber pendapatan untuk banyak orang dan sumber utama untuk ruang hidup, rekreasi, makanan, dan pendapatan bagi orang-orang yang tinggal di sekitar (Wilkinson \& Buddemeier, 1994).

Data keanekaragaman hayati terumbu karang diperlukan untuk pengembangan pengelolaan sumber daya terumbu karang, khususnya ikan karang. Data seperti ini merupakan potensi faktual yang dimiliki daerah dan potensi yang spesifik dimiliki daerah, seperti ada ikan endemik yang menjadi kekayaan daerah dan perlu diproteksi. Data keanekaragaman hayati dalam bentuk kuantitatif, seperti diwakili oleh indeks keanekaragaman, dapat pula digunakan untuk memperbaiki teknologi penangkapan. Indeks keanekaragaman rendah merupakan pertanda ada gangguan pada habitat dan karena pola-pola penangkapan yang merusak perlu diubah atau dihindari. Keanekaragaman hayati yang tinggi pada suatu wilayah juga merupakan indikasi bahwa telah terjadi kelestarian lingkungan hidup. Dengan demikian, rencana-rencana konservasi terbatas dan atau promosi untuk menggalakkan wisata bahari atau pengembangan sektor perikanan ikan hias akan menjadi suatu kebutuhan.

Secara ekologis, indeks-indeks keanekaragaman ikan karang adalah penting sebagai petunjuk terjadi perubahan dalam lingkungan hidup. Perubahanperubahan data keanekaragaman sumber daya ikan atau biota laut lain yang terukur secara periodik merupakan pertanda ada perubahan-perubahan 
habitat akibat dampak negatif dari pembangunan ekonomi. Ikan adalah indikator yang baik untuk menentukan kejadian-kejadian yang ekstrim atau gangguan pada habitat, karena ikan dapat merespon lebih cepat daripada biota lain terhadap gangguanganguan pada habitatnya (Gomez \& Yap, 1988).

Jadi data dan informasi keanekaragaman ikan karang secara periodik berguna untuk memprediksi kapasitas dan kesehatan lingkungan pesisir. Sejauh ini, data keanekaragaman hayati belum maksimal digali untuk memberikan asumsi-asumsi masalah lingkungan perairan pantai ketika berhadapan dengan ancaman degradasi lingkungan hidup.

Inventarisasi sumber daya ikan karang dilakukan untuk kepentingan pengembangan yang berkelanjutan dari sumber daya terumbu karang. Ketergantungan masyarakat pesisir Kabupaten Banggai pada sumber daya karang cukup besar. Industri pengolahan ikan asin batu-batu (ikan karang) terus berkembang dan sentra produksi tersebar di beberapa desa. Kabupaten Banggai memiliki lahan terumbu karang hampir di sepanjang garis pantai dan di beberapa gugus pulau yang terdiri atas 72 pulau, di mana wilayah tersebut termasuk dalam 9 kecamatan yang memiliki 131 desa pengembangan perikanan (Anonimous, 2003).

Tujuan penelitian ini adalah untuk menggali potensi kekayaan sumber daya ikan karang di wilayah tersebut, terutama untuk mengetahui berbagai indeks ekologis komunitas ikan karang yang meliputi kekayaan jenis, keanekaragaman jenis, kemerataan populasi, dominasi dan kepadatan ikan, serta persentase kelompok ikan karang.

\section{BAHAN DAN METODE}

Survei dilaksanakan pada bulan Juli 2006 di wilayah perairan karang Kabupaten Banggai, Sulawesi Tengah, di mana secara geografis terletak pada lintang $0^{\circ} 30^{\prime}-30^{\circ} 20^{\prime}$ dan bujur $122^{\circ} 23^{\prime}-125^{\circ} 30^{\prime}$ (Gambar 1). Stasiun penelitian dipilih berdasarkan pada analisis peta kerja yang disiapkan dari citra satelit.

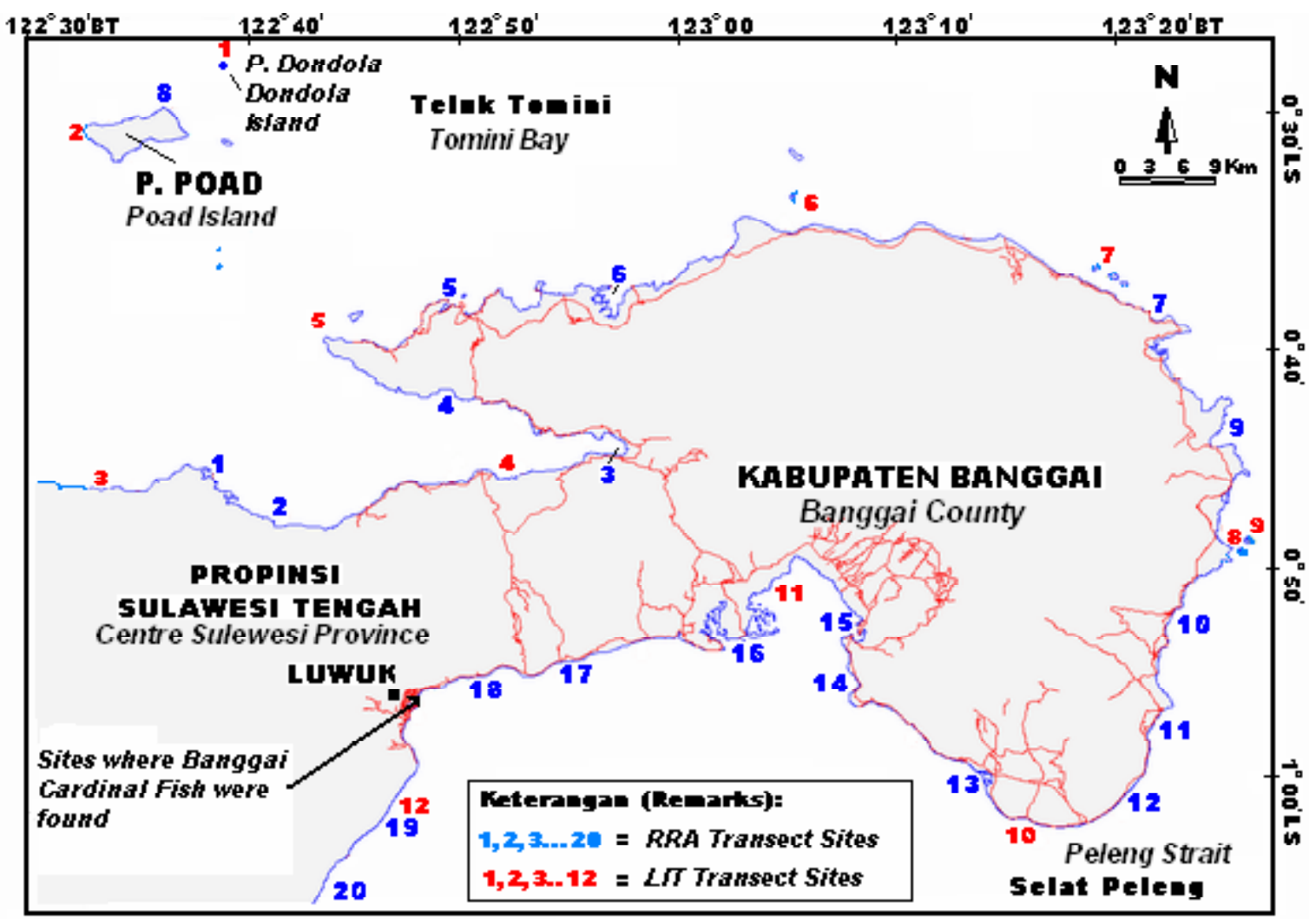

Gambar 1. Peta lokasi penelitian di Kabupaten Banggai, Sulawesi Tengah, yang menunjukkan tempattempat transek rapid reef assessment dan line intercept transect.

Fugure 1. Map of the study area in Banggai District, Central Sulawesi, showing rapid reef assessment and line intercept transect sites. 
Pendekatan dalam pengambilan data adalah dengan cara rapid reef assessment, line intercept transect, dan sensus visual. Cara rapid reef assessment dilakukan sebagai alternatif dari cara line intercept transect dengan mempertimbangkan luas lahan dan teknis pengaturan waktu penyelaman bebas dekompresi (no decompresion limit). Lokasi untuk penempatan transek rapid reef assessment ditentukan 20 titik dan untuk line intercept transect 12 titik. Rapid reef assessment juga dilakukan pada penyelaman pendahuluan untuk membuat daftar spesies baku yang akan digunakan pada sensus visual. Sensus visual ikan karang mengikuti titik-titik transek rapid reef assessment dan line intercept transect, di mana pada setiap titik transek tersebut ditentukan posisi geografis (Tabel 1 dan 2).

Pengambilan data ikan karang dengan metode rapid reef assessment dilakuan dengan cara snorkling pada titik transek rapid reef assessment yang sudah ditentukan dengan luas sensus $100 \mathrm{~m}^{2}$ selama 15 menit.

Rol meter dan SCUBA equipments khusus digunakan untuk pengambilan data dengan cara line intercept transect. Data ikan karang dikumpulkan dengan jalan sensus visual yang dikerjakan oleh penyelam sepanjang garis transek $50 \mathrm{~m}$, dengan luas lahan jelajah dan pandang $500 \mathrm{~m}^{2}$ (English et al., 1994). Jenis dan perkiraan jumlah ikan dicatat dalam data sheet kedap air. Identifikasi jenis ikan menggunakan buku petunjuk bergambar (Kuiter, 1992; Lieske \& Myers, 1994). Ikan karang dikelompokkan berdasarkan pada status, seperti ikan indikator, ikan major, dan ikan target (English et al., 1994). Ikan indikator adalah ikan kepe-kepe dari suku Chaetodontidae yang kehadiran dapat merefleksikan kondisi kesehatan karang. Ikan major adalah golongan ikan hias dan non ikan hias yang selalu berasosiasi dengan karang, baik sebagai penetap maupun pelintas. Ikan target adalah ikan konsumsi.

Analisis keanekaragaman hayati ikan karang menggunakan beberapa indeks yang dianggap penting sebagai baseline data. Indeks-indeks tersebut adalah indeks kekayaan jenis (Richness indices), indeks keanekaragaman (Diversity indices), dan indeks keseragaman jenis (Evenness indices) (Ludwig \& Reynold, 1988).

Indeks kekayaan jenis mengacu pada:

Indeks Margalef $\mathrm{R}=(\mathrm{S}-1) / \ln (\mathrm{n})$ di mana:

$\mathrm{S}=$ banyak jenis

$\mathrm{n}=$ jumlah individu ikan untuk semua jenis

Indeks keanekaragaman mengacu pada:

Indeks Shannon $\mathrm{H}=\Sigma\{(\mathrm{n} / \mathrm{N}) \ln (\mathrm{n} / \mathrm{N})\} \ldots \ldots \ldots$. (2

Indeks Simpson $\lambda=\sum\left\{\left(\mathrm{n}_{i}\left(\mathrm{n}_{\mathrm{i}}-1\right) /(\mathrm{N}(\mathrm{N}-1)\} \ldots .\right.\right.$. (3

Indeks Dominasi $\mathrm{D}=\sum\left(\mathrm{n}_{\mathrm{i}} / \mathrm{N}\right)^{2} \ldots \ldots \ldots \ldots \ldots \ldots \ldots . . . . . . .14$

di mana:

$\mathrm{n}_{\mathrm{i}}=$ jumlah ikan jenis ke-i

$\mathrm{N}=$ total individu ikan untuk semua jenis

$\mathrm{H}=$ Indeks Shannon

(Catatan/Note: hasil perhitungan indeks dominasi $=$ hasil perhitungan indeks Simpson)

Indeks Hill-diversity number $\mathrm{N}_{1}=\mathrm{e}^{\mathrm{H}}$ dan $\mathrm{N}_{2}=1 / \lambda$. (5

di mana:

$\mathrm{N}_{1}$ = populasi dari suatu spesies bergerombol atau individual yang dijumpai dalam jumlah banyak

$\mathrm{N}_{2}$ = populasi dari suatu spesies bergerombol atau individual yang dijumpai dalam jumlah paling banyak

$\mathrm{H}=$ Indeks Shannon

$\mathrm{e}=$ bilangan epsilon atau natural

$\lambda=$ Indeks Simpson

Indeks keseragaman jenis mengacu pada:

Indeks Pielou $\mathrm{E}=\{\mathrm{H} / \mathrm{ln}(\mathrm{S})$

di mana:

$\mathrm{S}=$ banyak jenis

$\mathrm{H}=$ Indeks Shannon

Kisaran nilai indeks keanekaragaman $(H)$ berdasarkan pada modifikasi kisaran yang diklasifikasikan dan dimodifikasi dari Mason (1981) sebagai berikut:

$\mathrm{H}<2,30 \quad$ : keanekaragaman populasi rendah

$2,30<\mathrm{H}<3,45$ : keanekaragaman populasi sedang

$3,46<\mathrm{H}<5,75$ : keanekaragaman tinggi

$5,76<\mathrm{H}<6,90$ : keanekaragaman sangat tinggi

Kisaran indeks dominasi (D) berada pada skala 0 sampai dengan 1 . Semakin mendekati 0 berarti tidak ada populasi yang mendominasi dalam suatu komunitas. Hal ini, menunjukkan ada keanekaragaman populasi yang tinggi. Sebaliknya 
ketika mendekati nilai 1 , berarti ada 1 atau lebih spesies yang mendominasi dalam komunitas. Hal ini, sering terjadi pada lingkungan yang ekstrim akibat polusi, sehingga indeks keanekaragaman menjadi rendah. Krebs (1989) membagi kisaran nilai indeks dominasi menjadi:

$0,00<D \leq 0,30$ : dominasi rendah

$0,30<\mathrm{D} \leq 0,60$ : dominasi sedang

$0,60<\mathrm{D} \leq 1,00$ : dominasi tinggi

Indeks keseragaman jenis (E) berkisar antara nilai 0 sampai dengan 1. Krebs (1989) mengklasifikasikan kisaran indeks ini menjadi:

$E<1$ : keseragaman spesies tinggi

$0,4<\mathrm{E}<0,6 \quad$ :keseragaman spesies sedang

$\mathrm{E}<0,4 \quad$ : keseragaman spesies rendah
Kepadatan ikan karang merupakan perhitungan jumlah individu yang tersensus per satuan luas transek (50x10 m). Menurut Djamali \& Darsono (2005), secara kualitatif kisaran kepadatan individu per $\mathrm{m}^{2}$ diklasifikasikan sebagai berikut:

$$
\begin{array}{ll}
1-5 & \text { : sangat jarang } \\
5-10 & \text { : jarang } \\
10-20 & \text { : cukup melimpah } \\
20-50 & \text { : melimpah } \\
>50 & \text { : sangat melimpah }
\end{array}
$$

\section{HASIL DAN BAHASAN}

Jenis-jenis ikan karang yang berhasil diidentifikasi pada seluruh wilayah penelitian di perairan Kabupaten Banggai, menurut lokasi transek rapid reef

\begin{tabular}{|c|c|c|c|}
\hline \multirow{2}{*}{$\begin{array}{c}\begin{array}{c}\text { Lokasi transek/ } \\
\text { Transect sites }\end{array} \\
1\end{array}$} & \multicolumn{2}{|c|}{$\begin{array}{c}\text { Posisi geografis/ } \\
\text { Geographic positions }\end{array}$} & \multirow{2}{*}{$\begin{array}{c}\begin{array}{c}\text { Nama wilayah/ } \\
\text { Area names }\end{array} \\
\text { Tongkonunuk }\end{array}$} \\
\hline & $00^{\circ} 45^{\prime} 51,9^{\prime \prime}$ & $122^{\circ} 38^{\prime 21,3 "}$ & \\
\hline 2 & $00^{\circ} 48^{\prime} 16,9^{\prime \prime}$ & $122^{\circ} 44^{\prime 23,1 "}$ & Sepa \\
\hline 3 & $00^{\circ} 45^{\prime} 08,4^{\prime \prime}$ & $122^{\circ} 56^{\prime} 59,9^{\prime \prime}$ & Siuna \\
\hline 4 & $00^{\circ} 42 ' 20,6^{\prime \prime}$ & $122^{\circ} 49^{\prime} 25,8^{\prime \prime}$ & Siuna \\
\hline 5 & $00^{\circ} 38^{\prime} 07,5^{\prime \prime}$ & $122^{\circ} 49^{\prime} 59,8^{\prime \prime}$ & Tikupon \\
\hline 6 & $00^{\circ} 37^{\prime} 00,1^{\prime \prime}$ & $122^{\circ} 57^{\prime} 19,7^{\prime \prime}$ & Toiba \\
\hline 7 & $00^{\circ} 00^{\prime} 00,0^{\prime \prime}$ & $122^{\circ} 00^{\prime} 00,0^{\prime \prime}$ & Pangkalasean \\
\hline 8 & $00^{\circ} 28^{\prime} 43,6^{\prime \prime}$ & $122^{\circ} 36^{\prime} 17,3^{\prime \prime}$ & Pulau Poad \\
\hline 9 & $00^{\circ} 44^{\prime} 47,0^{\prime \prime}$ & $123^{\circ} 36^{\prime} 17,3^{\prime \prime}$ & Ondoliang \\
\hline 10 & $00^{\circ} 56^{\prime} 49,7^{\prime \prime}$ & $123^{\circ} 23^{\prime} 38,5^{\prime \prime}$ & Sepe \\
\hline 11 & $00^{\circ} 59^{\prime} 09,1^{\prime \prime}$ & $123^{\circ} 22^{\prime} 46,4^{\prime \prime}$ & Lonas \\
\hline 12 & $01^{\circ} 02 ' 02,4^{\prime \prime}$ & $123^{\circ} 21^{\prime} 12,5^{\prime \prime}$ & Sulubombong \\
\hline 13 & $01^{\circ} 01^{\prime} 16,6^{\prime \prime}$ & $123^{\circ} 14^{\prime} 54,5^{\prime \prime}$ & Binotik \\
\hline 14 & $01^{\circ} 56^{\prime} 30,9^{\prime \prime}$ & $123^{\circ} 08^{\prime} 38,0^{\prime \prime}$ & Serom \\
\hline 15 & $01^{\circ} 53^{\prime} 05,4^{\prime \prime}$ & $123^{\circ} 08^{\prime 23,4 "}$ & Baruga \\
\hline 16 & 0154'01,8" & $123^{\circ} 04^{\prime} 13,4^{\prime \prime}$ & Wedikan \\
\hline 17 & $01^{\circ} 55^{\prime} 13,7^{\prime \prime}$ & $122^{\circ} 55^{\prime} 00,7^{\prime \prime}$ & Bunga \\
\hline 18 & $01^{\circ} 55^{\prime} 54,0^{\prime \prime}$ & $122^{\circ} 50^{\prime} 49,0^{\prime \prime}$ & Kilongan \\
\hline 19 & $01^{\circ} 02 ' 36,5^{\prime \prime}$ & $122^{\circ} 46^{\prime} 18,0^{\prime \prime}$ & Bubung \\
\hline 20 & $01^{\circ} 07^{\prime} 15,9^{\prime \prime}$ & $122^{\circ} 42^{\prime} 53,7^{\prime \prime}$ & Nambopadang \\
\hline
\end{tabular}

Tabel1. Posisi geografis dan administratif transek rapid reef assessment sensus ikan karang di Kabupaten Banggai, Sulawesi Tengah

Table 1. Geographic and administrative positions of rapid reef assessment reef fish census transects in Banggai District, Central Sulewesi

assessment dan line intercept transect, disajikan pada Lampiran 1. Tabel ini menunjukkan bahwa pada keseluruhan lahan terumbu karang di mana sensus dilakukan berhasil diidentifikasi 324 jenis dan 121 marga ikan karang dari 40 suku, dengan variasi antara lokasi berkisar antara 14 sampai dengan 140 jenis ikan karang.

Kondisi keanekaragaman jenis yang ditemukan di Kabupaten Banggai lebih baik dari kondisi keanekaragaman ikan karang di perairan Maros, Pangkep, Takalar, (Sulawesi Selatan), Lembata (Nusa Tenggara Timur), dan Kangean (Madura). Kondisi keanekaragaman tersebut hampir sama tinggi dengan keanekaragaman yang dijumpai di Bali. Keanekaragaman ikan di Kabupaten Banggai lebih rendah dari keanekaragaman ikan di Kepulauan Banda, Maluku Tengah, dan perairan Pulau Halmahera, Maluku Utara. Perairan Maros dan di sekitar memiliki 142 jenis dengan variasi antar lokasi 
48 sampai dengan 122 jenis (Djamali, 2005). Perairan Pulau Lembata memiliki 195 jenis, 95 marga, dan 36 suku (Edrus et al., 2004). Perairan Pulau Kangean memiliki 204 jenis, 89 marga, dan 34 suku (Siswantoro et al., 2003). Bali memiliki 314 jenis, 111 marga, dan 47 suku (Edrus \& Suprapto, 2005); perairan Kepulauan Banda memiliki 388 jenis, 140 marga dan 45 suku (Edrus et al., 1992). Perairan Pulau
Halmahera memiliki 397 jenis dari 45 suku (Anonimous, 2006).

Tinggi keanekaragaman dan besar variasi jumlah jenis antar transek yang ditemukan di perairan Kabupaten Banggai (Tabel 3 dan 4) dapat dijelaskan dengan mengacu pada pendapat Nybakken (1988). Menurut Nybakken (1988), ikan merupakan organisme

Tabel2. Posisi geografis dan administratif transek line intercept transect sensus ikan karang di Kabupaten Banggai, Sulawesi Tengah

Table 2. Geographic and administrative positions of line intercept transect reef fish census transects in Banggai District, Central Sulewesi

\begin{tabular}{cccc}
\hline $\begin{array}{c}\text { Lokasi transek/ } \\
\text { Transect sites }\end{array}$ & \multicolumn{2}{c}{$\begin{array}{c}\text { Posisi geografis/ } \\
\text { Geographic positions }\end{array}$} & $\begin{array}{c}\text { Nama wilayah/ } \\
\text { Area names }\end{array}$ \\
\hline 1 & $00^{\circ} 25^{\prime} 14,2^{\prime \prime}$ & $122^{\circ} 38^{\prime} 09,5^{\prime \prime}$ & Pulau Dondola \\
2 & $00^{\circ} 30^{\prime} 35,7^{\prime \prime}$ & $122^{\circ} 31^{\prime} 47,5^{\prime \prime}$ & Pulau Poad \\
3 & $00^{\circ} 46^{\prime} 06,8^{\prime \prime}$ & $122^{\circ} 30^{\prime} 50,2^{\prime \prime}$ & Lobu \\
4 & $00^{\circ} 46^{\prime} 08,7^{\prime \prime}$ & $122^{\circ} 51^{\prime} 38,7^{\prime \prime}$ & Taipan \\
5 & $00^{\circ} 39^{\prime} 46,6^{\prime \prime}$ & $122^{\circ} 43^{\prime} 13,2^{\prime \prime}$ & Tanjung Jepara \\
6 & $00^{\circ} 32^{\prime} 57,9^{\prime \prime}$ & $123^{\circ} 05^{\prime} 52,4^{\prime \prime}$ & Pulau Mentawa \\
7 & $00^{\circ} 36^{\prime} 50,0^{\prime \prime}$ & $123^{\circ} 21^{\prime} 10,3^{\prime \prime}$ & Pulau Empat \\
8 & $00^{\circ} 49^{\prime} 42,3^{\prime \prime}$ & $123^{\circ} 27^{\prime} 05,0^{\prime \prime}$ & Pulau Dua \\
9 & $00^{\circ} 48^{\prime} 51,2^{\prime \prime}$ & $123^{\circ} 27^{\prime} 19,4^{\prime \prime}$ & Pulau Dua \\
10 & $01^{\circ} 03^{\prime} 01,6^{\prime \prime}$ & $123^{\circ} 17^{\prime} 32,15^{\prime \prime}$ & Bollo \\
11 & $00^{\circ} 50^{\prime} 49,7^{\prime \prime}$ & $123^{\circ} 23^{\prime} 38,5^{\prime \prime}$ & Tanjung Lamala \\
12 & $01^{\circ} 03^{\prime} 47,8^{\prime \prime}$ & $122^{\circ} 44^{\prime} 58,7^{\prime \prime}$ & Bubung \\
\hline
\end{tabular}

yang terbanyak dan paling mudah dilihat di lahan terumbu karang. Oleh karena itu, jumlah yang besar dan mengisi seluruh bagian di wilayah terumbu, ikan karang berperan penting dalam ekosistem terumbu karang. Daerah Indo-Pasifik bagian tengah merupakan wilayah pusat keanekaragaman hayati laut tertinggi. Philipina dan Indonesia terletak pada wilayah tersebut. Perairan ke-2 negara tersebut mempunyai jumlah jenis yang sangat tinggi dan jumlah jenis tersebut akan semakin berkurang jika menjauhi wilayah pusat tinggi keanekaragaman tersebut. Jumlah spesies yang terdapat di sebuah lahan terumbu karang tunggal dapat mencapai 500 spesies. Keanekaragaman yang tinggi ini berkaitan dengan keanekaragaman ruang, relung ekologi, jenis habitat, dan interaksi spesies yang terbentuk dalam ekosistem terumbu karang, seperti terbentuk simbion dan hubungan mutualisme antar jenis organisme penghuni terumbu karang. Keanekaragaman hayati yang tinggi seperti ini ditemukan pada kondisi terumbu dan lingkungan perairan yang sehat. Dengan demikian, sebuah lahan terumbu karang yang sehat dapat menampung sejumlah besar ikan karang dengan fungsi masingmasing dalam hubungan yang spesifik antara organisme dan habitat serta antara biota dengan biota.
Sebaliknya, dalam kondisi terumbu karang mengalami degradasi kualitas dan kuantitas, baik pada habitat maupun hubungan intra dan antar populasi ikan akan turut mengalami degradasi dan musnah. Pasca degradasi, sesuatu yang tersisa adalah sebagian kecil terumbu dan habitat-habitat lain seperti pasir, lumpur, atau pecahan kecil karang mati dan juga akan terjadi kekeruhan yang tinggi. Penghuni yang mampu bertahan hanya beberapa jenis ikan dengan perkembangan populasi yang meningkat. Pertumbuhan populasi dalam kondisi seperti ini disebabkan oleh ada kemampuan beradaptasi pada massa air dengan kualitas tertentu, pada mekanisme hubungan antar dan intra populasi, pada jaring makanan yang tersedia dan spesialisasi ikan itu sendiri dalam konsep relung ekologi (Odum, 1975). Pada kondisi lingkungan yang mengalami degradasi atau di bawah pengaruh polusi, jumlah individu dalam 1 populasi dari jenis tertentu meningkat dan jumlah jenis dalam komunitas menurun karena ada pembatasan tertentu. Itu yang membedakan tingkat keanekaragaman ikan karang dari satu lahan terumbu karang dengan lahan terumbu karang yang lain. 
Variasi kehadiran jenis ikan karang bergantung pada kondisi terumbu karang di masing-masing lahan penelitian. Setiap lokasi penelitian memiliki kondisikondisi tertentu dari kesehatan dan jumlah jenis karang, keberagaman lifeform biota karang dan keberagaman dari substrat dasar perairan. Keanekaragaman terumbu karang akan berpengaruh pada keanekaragaman ikan karang, karena terumbu mempunyai kapasitas yang besar ditinjau dari relung ekologi dan bentuk interaksi populasi dalam komunitas ikan karang (Supriharyono, 2000).

Tabel 3 dan 4 menunjukkan bahwa lokasi perairan Kabupaten Banggai yang memiliki indeks keanekaragaman yang tinggi meliputi perairan Pulau Dondola, Pulau Poad, Tanjung Jepara, Tanjung Lamala, dan perairan Desa Bubung. Perairan lain tergolong perairan dengan indeks keanekaragaman sedang. Tingkat kepadatan per $\mathrm{m}^{2}$ tergolong jarang untuk semua lokasi penelitian (kurang dari 10 ekor $\left.m-{ }^{2}\right)$.

Tingkat kestabilan antar populasi dalam komunitas ikan tergolong baik pada semua lokasi penelitian, seperti ditunjukkan oleh nilai indeks dominasi yang semua masuk pada kriteria rendah dengan nilai keseragaman populasi yang tinggi pada semua lokasi penelitian (Tabel 3 dan 4). Hal ini, berarti bahwa setiap individu atau koloni dari populasi ikan karang memiliki kesempatan yang sama untuk mendiami suatu habitat terumbu karang.

Perairan karang yang memiliki kenekaragaman dalam hal jumlah individu yang tinggi (N1 dan N2) adalah perairan Tongkonunuk, Siuna, Pangkalasean, Pulau Poad, Ondoliang, Sulubombong, Serom, Wedikan, Bubung, dan Nambopadang. Kelompokkelompok yang berkoloni ini adalah Plotosus lineatus, Pseudanthias spp., Apogon spp., Sphaeramia nematoptera, Caesio spp., Pterocaesio spp., Abudefduf spp., Chromis spp., Chrysiptera spp., Dascyllus spp., Pomacentrus spp., Halichoeres chrysus, Melichthys vidua, dan Rastrelliger karnagurta.

Lokasi perairan yang memiliki kelompok ikan target (konsumsi) terbanyak jumlah individu meliputi perairan Ondoliang, Sulubombong, dan Bubung. Selain itu, ikan tangkapan nelayan yang terbanyak dari segi jumlah jenis meliputi perairan Tongkonunuk, Siuna, Toiba, Pangkalasean, Pulau Poad, Ondoliang, Sepe, Binotik, Baruga, Kilongan, Bubung, dan Nambopadang (Tabel 3 dan 4). Sedangkan kelompok ikan hias terdapat hampir di seluruh pesisir Kabupaten Banggai. Distribusi spasial dari jenis-jenis ikan tersebut dapat dilihat pada Lampiran 1. 


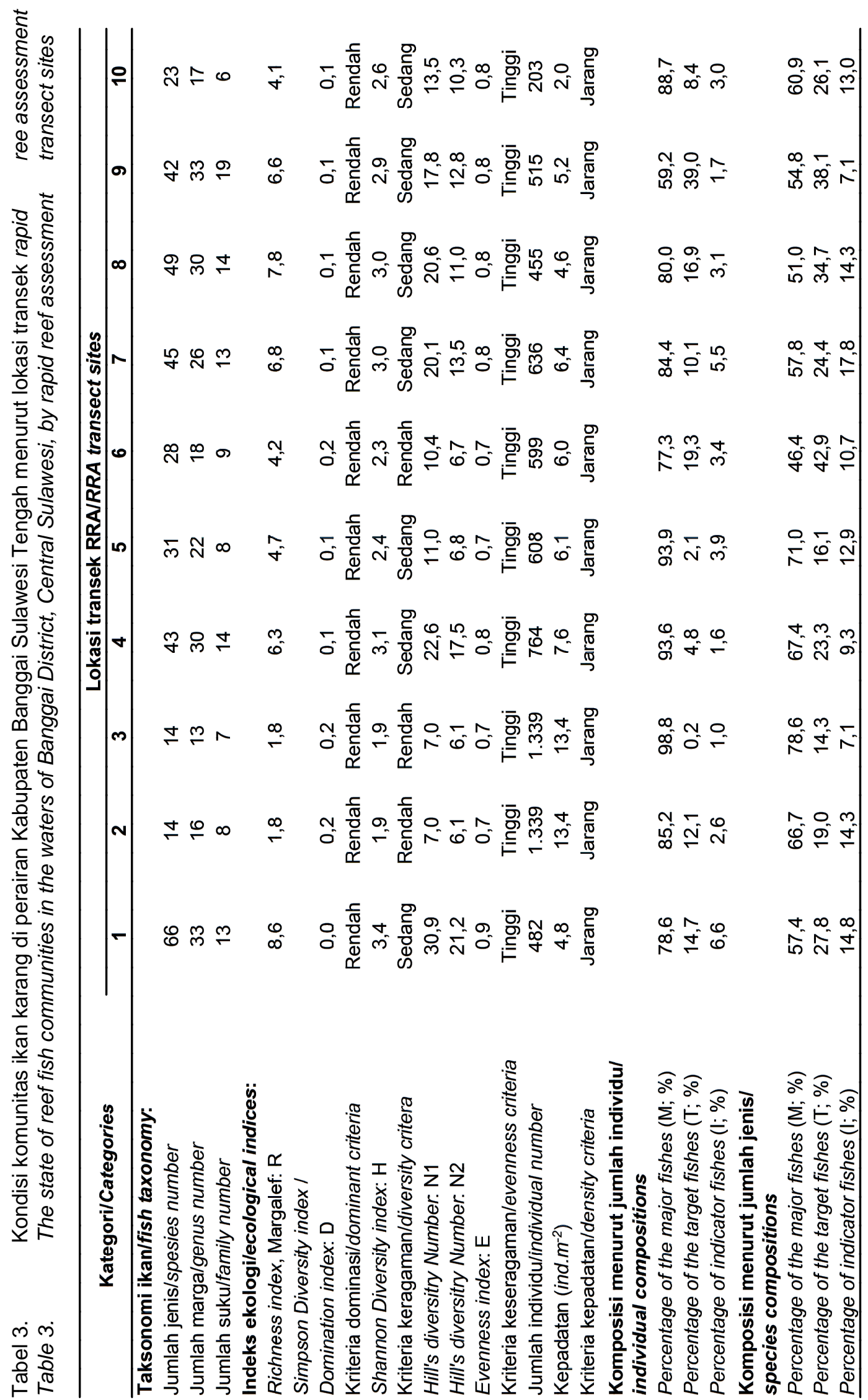




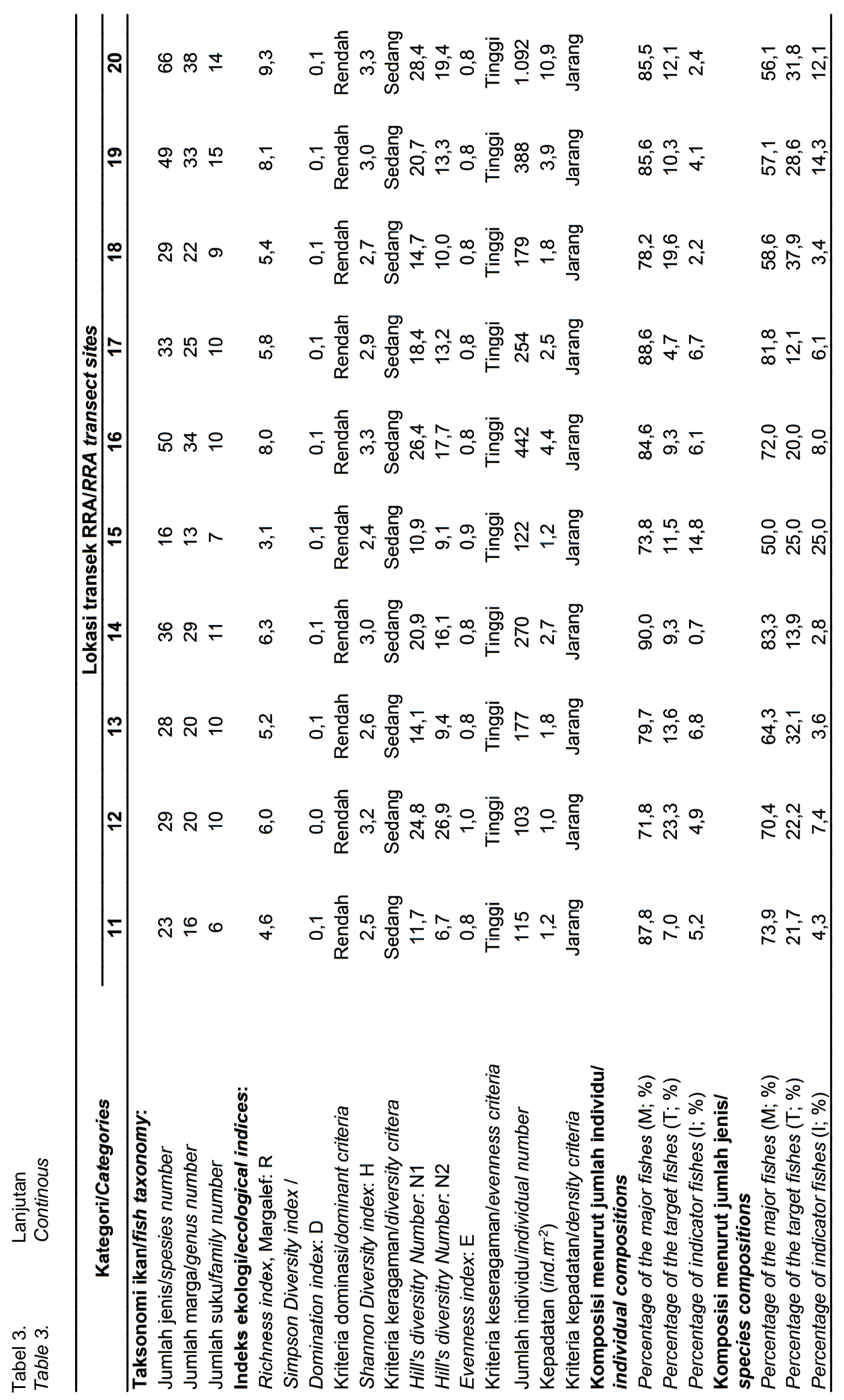




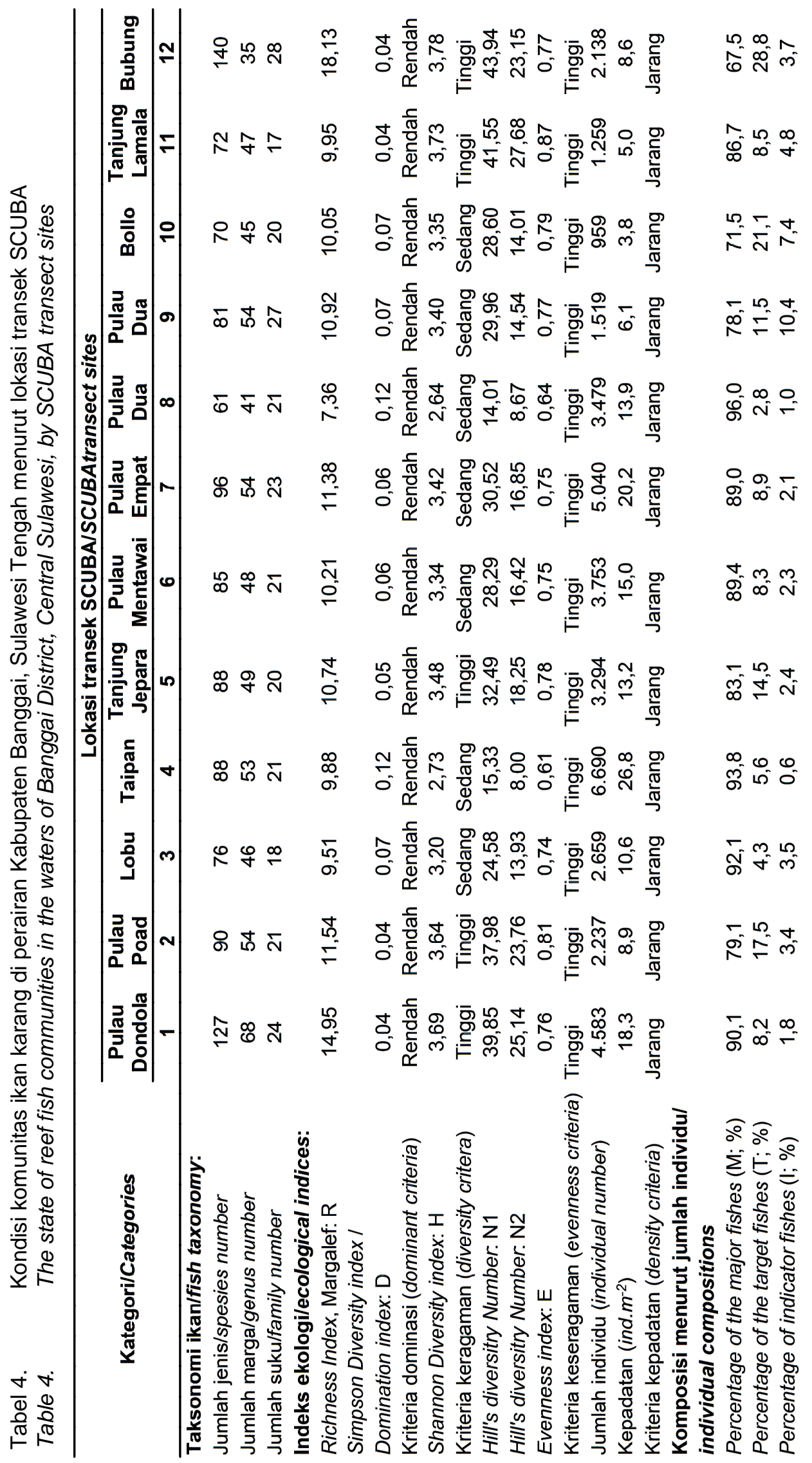




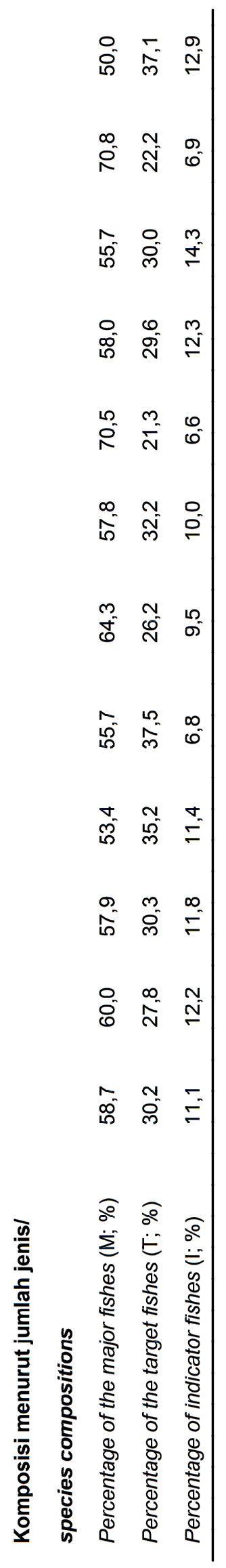




\section{KESIMPULAN DAN SARAN}

\section{Kesimpulan}

1. Dari 32 lokasi transek, total ikan karang yang teridentifikasi di perairan Kabupaten Banggai adalah 324 jenis dan 121 marga ikan karang dari 40 suku, dengan variasi antara lokasi berkisar pada 14 sampai dengan 140 jenis ikan karang. Sebanyak $26 \%$ antara lain jenis-jenis ikan yang termasuk kelompok ikan konsumsi ekonomis penting dan $27 \%$ tergolong ikan hias laut ekonomis penting.

2. Sebanyak 6 lokasi dari 32 lokasi transek di perairan Kabupaten Banggai memiliki indeks keanekaragaman ikan karang yang tinggi. Lokasi tersebut meliputi perairan Pulau Dondola, Pulau Poad, Tanjung Jepara, Tanjung Lamala, dan perairan Desa Bubung. Perairan lain, yaitu 23 lokasi transek tergolong perairan dengan indeks keanekaragaman sedang dan 3 lokasi tergolong memiliki keanekaragaman rendah.

3. Tingkat kepadatan ikan karang per $\mathrm{m}^{2}$ tergolong jarang untuk semua lokasi penelitian, yaitu kurang dari 30 ekor $\mathrm{m}^{-2}$.

4. Keseragaman atau keseimbangan antara populasi dalam komunitas ikan tergolong tinggi pada semua lokasi penelitian.

5. Nilai indeks dominasi pada semua lokasi penelitian masuk pada kriteria rendah.

6. Jenis-jenis ikan karang yang hidup bergerombol (schooling population) terbanyak dijumpai pada perairan Tongkonunuk, Siuna, Pangkalasean, Pulau Poad, Ondoliang, Sulubombong, Serom, Wedikan, Bubung, dan Nambopadang.

7. Jumlah individu terbanyak kelompok ikan konsumsi dijumpai pada perairan Ondoliang, Sulubombong, dan Bubung. Sedangkan jumlah jenis terbanyak kelompok ikan konsumsi dijumpai di perairan Tongkonunuk, Siuna, Toiba, Pangkalasean, Pulau Poad, Ondoliang, Sepe, Binotik, Baruga, Kilongan, Bubung, dan Nambopadang.

8. Kelompok ikan mayor, baik dalam jumlah individu maupun jumlah jenis, mendominasi kelompok ikan karang untuk semua lokasi penelitian.

\section{Saran}

1. Ancaman sedimentasi dari daratan terhadap eksistensi terumbu karang dan ikan karang perlu mendapat perhatian yang serius oleh Instansi Pemerintah Daerah terkait.

2. Wilayah perairan karang Pulau Dondola, Pulau Mentawai, Pulau Empat, dan Pulau Dua perlu dikonservasi dengan menetapkan sebagai lahan perlindungan laut atau wilayah wisata bahari.

3. Wilayah pemanfaatan perikanan karang tangkap (fishing grounds) perlu ditetapkan dengan pola pengelolaan berbasis masyarakat (CommunityBased Resource Management Areas). Lokasilokasi kandidat meliputi perairan Tongkonunuk, Siuna, Toiba, Pangkalasean, Pulau Poad, Ondoliang, Sepe, Binotik, Baruga, Kilongan, Bubung, dan Nambopadang.

4. Misi, visi, dan strategi pengelolaan sumber daya terumbu karang berbasis masyarakat perlu disusun untuk pemanfaatan dan sekaligus penyelamatan perairan karang (KPP-COREMAP, 2001). Lokasi-lokasi tersebut (item 3) memiliki dokumen resmi yang dirumuskan dan ditetapkan oleh masyarakat setempat dan pemerintah daerah Kabupaten Banggai.

\section{PERSANTUNAN}

Kegiatan dari hasil riset pemetaan sumber daya alam laut Kabupaten Banggai, T.A. 2006, di Badan Koordinasi Survei dan Pemetaan Nasional, CibinongBogor.

\section{DAFTAR PUSTAKA}

Anonimous. 2003. Laporan kemajuan. Penyusunan Tata Ruang Pesisir dan Pulau-pulau Kecil di Kabupaten Donggala dan Banggai Propinsi Sulawesi Tengah. Dinas Perikanan dan Kelautan Prop. Sulawesi Tengah.

Anonimous. 2006. Kajian analisis dan data revitalisasi pertanian, perikanan, dan kehutanan. Kerja sama antara Badan Pemerintah Daerah Maluku Utara dan BPTP Maluku Utara. Ternate. h. 40.

Djamali, A. 2005. Hasil penelitian potensi sumber daya karang dan ikan karang di perairan Maros, Pangkep, dan Takalar, Sulawesi Selatan, pada 
bulan Agustus 2004. Laporan proyek. P3O. Lembaga Ilmu Pengetahuan Indonesia. Jakarta.

Djamali, A. \& P. Darsono. 2005. Petunjuk teknis lapangan untuk penelitian ikan karang di ekosistem terumbu karang. Materi Kursus. Pusat Dokumentasi dan Informasi IImiah. Lembaga IImu Pengetahuan Indonesia. Jakarta.

Edrus, I. N., A. R. Syam, \& La Sui. 1992. Potensi, pemanfaatan, dan prospek pengembangan perikanan karang di Kepulauan Banda, Maluku Tengah, dalam hubungannya dengan Kepariwisataan. Jurnal Penelitian Perikanan Laut. 74. 32-39.

Edrus, I. N., Suprapto, \& I. Suprihanto. 2004. Komunitas ikan karang di perairan Pulau Lembata, Nusa Tenggara Timur. Dalam Ekologi dan Potensi Sumber Daya Perikanan Lembata Nusa Tenggara Timur. Pusat Riset Perikanan Tangkap. Departemen Kelautan dan Perikanan.

Edrus, I. N. \& Suprapto. 2005. The current state of artificial reefs in Lebah Coastal waters, Karangasem, Bali: An evaluation on the coastal resource rehabilitation project. Indonesian Fisheries Research Journal. Vol.11 (1). 19-40.

English, S., C. Wilkinson, \& V. Baker.1994. Survei manual for tropical marine resources. Australian Institute of Marine Science. Townsville. Australia.

Gomez, E. D. \& H. T. Yap. 1984. Monitoring reef condition. In Coral reef management handbook. R. A. Kenchingt6on and B. E. T. Hudson (Eds). Unesco Publisher. Jakarta. p. 171.

Krebs, C. J. 1989. Ecological methodology. Harper Collins Publishing Inc. New York.
Kuiter, R. H. 1992. Tropical reef fishes of the western Pacific Indonesia and adjacent waters. Gramedia. Jakarta.

Lieske, E. \& R. Myers. 1997. Reef fishes of the world. Periplus Edition. Jakarta. Indonesia.

Ludwig, J. A. \& J. F. Reynolds. 1988. Statistical ecology. A primer on methods and computing. Jhon Wiley \& Son. New York. 337 p.

Mason, C. F. 1981. Biology of freshwater pollution. Longman Scientific and Technical. Longman Singapore Publisher Ptc. Ltd. Singapore.

Nash, S. V. 1989. Reef diversity index survei method for non specialist. Tropical Coastal Area Management. Vol.4 (3). 14-17.

Nybakken, J. W. 1988. Biologi laut suatu pendekatan ekologis (Terjemahan M. Eidman, Koesoebiono, Dietriech G. B., M. Hutomo, dan Sukristijono). Penerbit PT. Gramedia. Jakarta.

Odum, E. P. 1975. Fundamental of ecology. E. B. Sounders Co. Philadelphia. 574 pp.

Siswantoro, Y., I. N. Edrus, \& I. Suprihanto. 2003. Inventarisasi dan pemetaan sumber daya ikan karang pada perairan Pulau Kangean. Bakosurtanal. Jakarta.

Supriharyono. 2000. Pengelolaan ekosistem terumbu karang. Penerbit Jembatan. Jakarta. h. 81.

Wilkinson, C. R. \& R. W. Buddemeier. 1994. Global climate change and coral reefs: Implications for people and reefs. Report of the UNEP-IOC-ASPEIIUCN Global Task Team on the Implication of Climate Change on Coral Reefs. IUCN Publications Service Unit. Cambridge. 
Sumber Daya Ikan Karang Perairan Kabupaten Banggai, Sulawesi Tengah (Saputro, G.B. \& Isa N.E.)

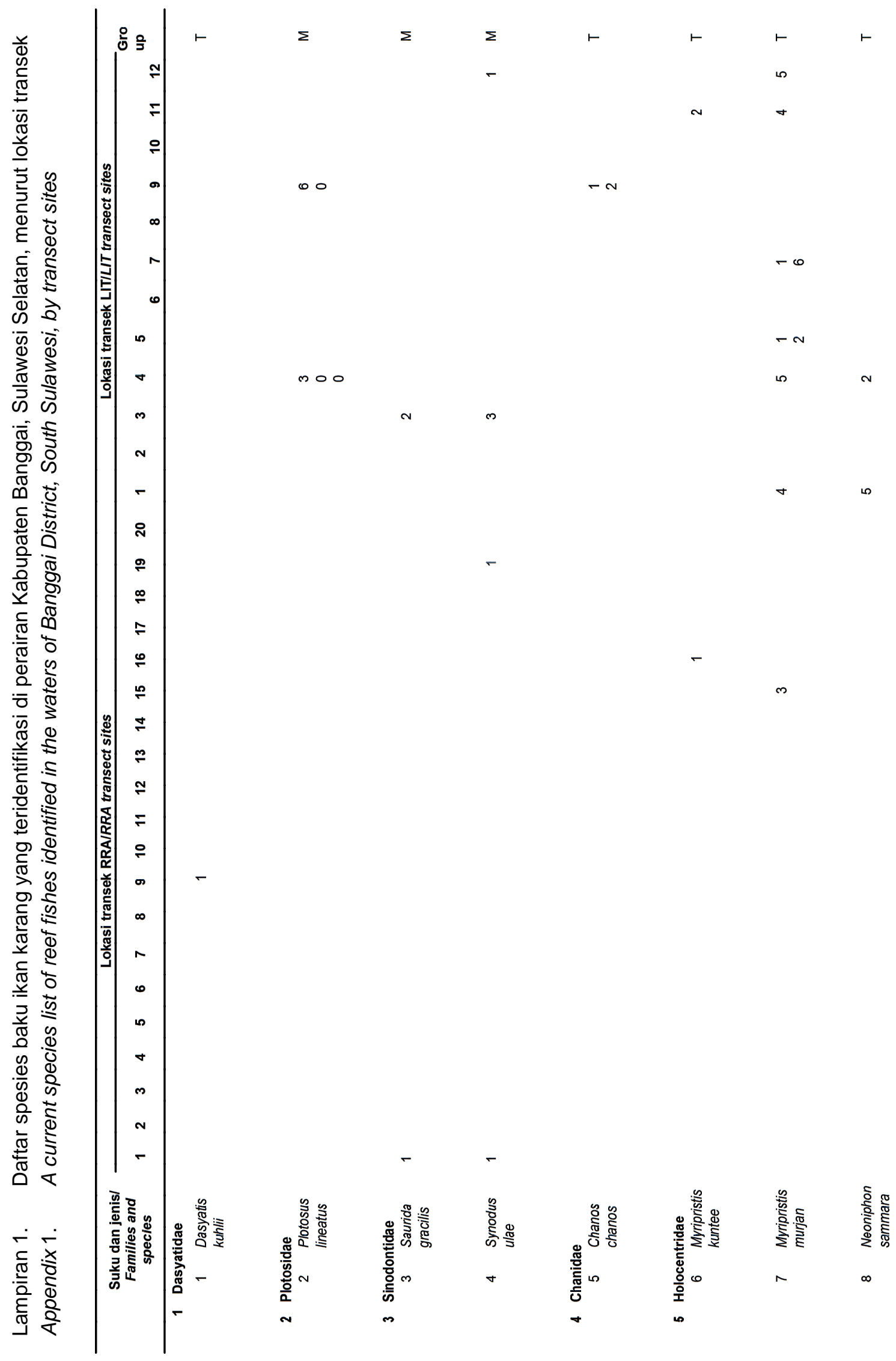




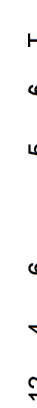

6

$\checkmark$

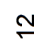

N

N

N

N

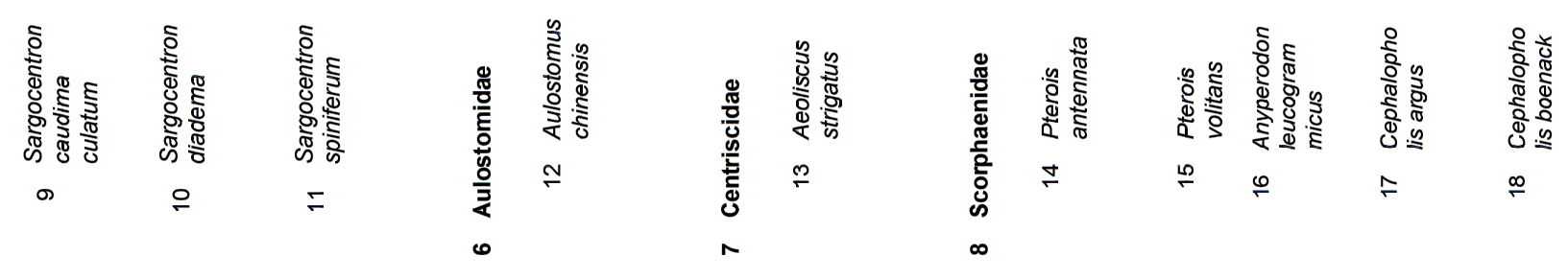


Sumber Daya Ikan Karang Perairan Kabupaten Banggai, Sulawesi Tengah (Saputro, G.B. \& Isa N.E.)

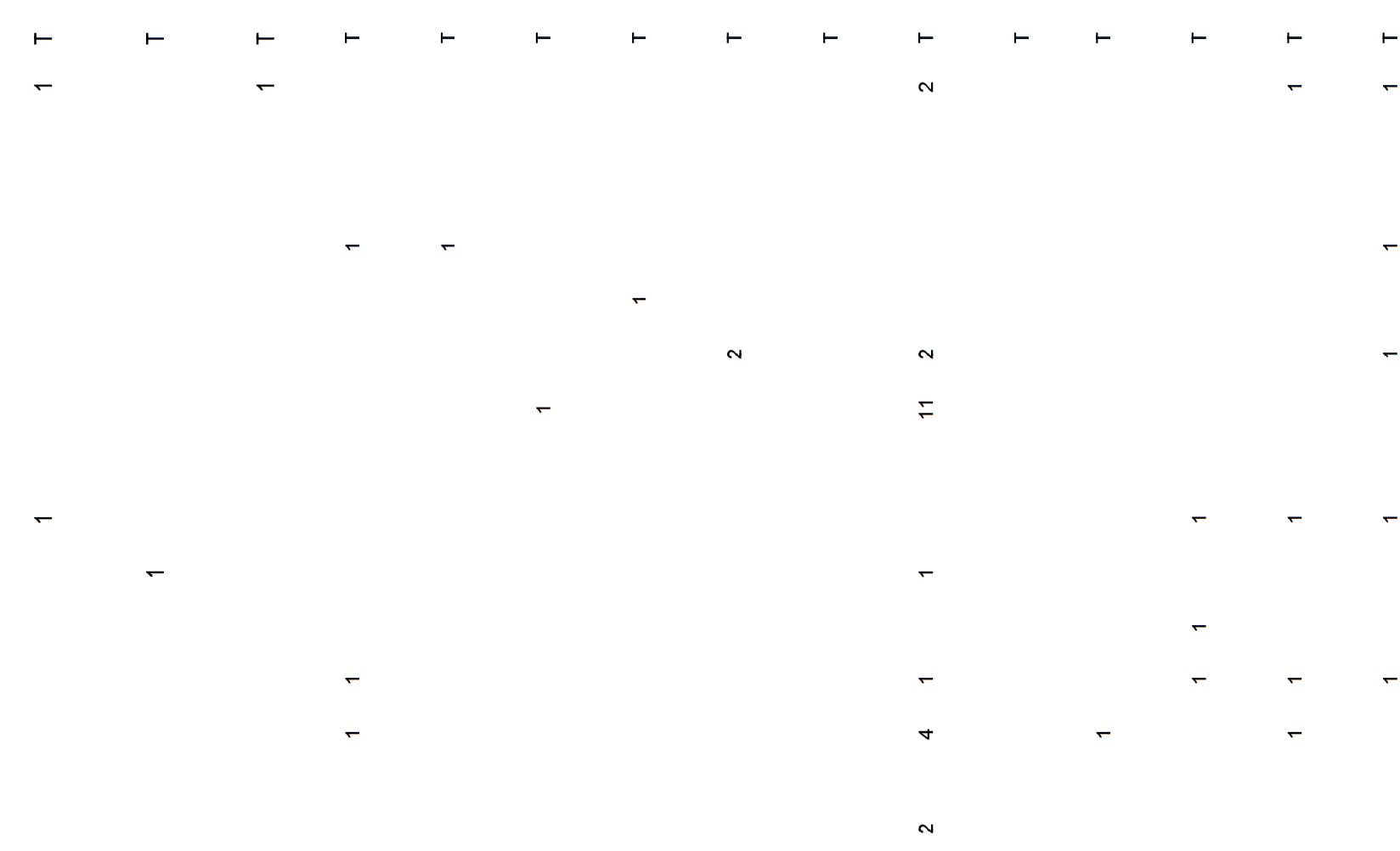

N

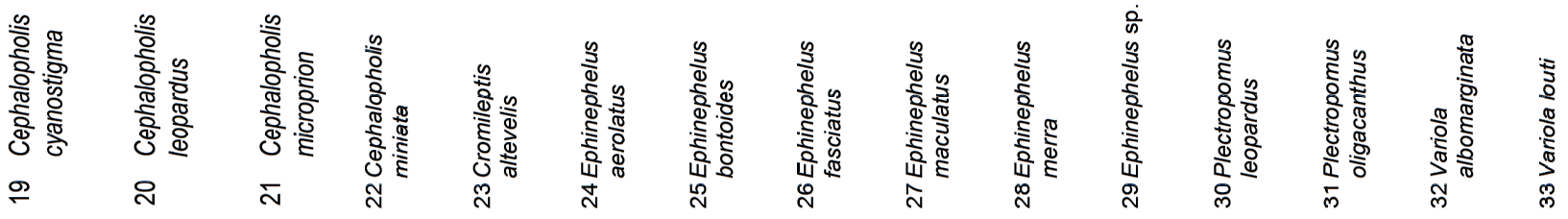




$$
\begin{aligned}
& \sum \quad \sum \quad \sum \\
& \text { =0 ลิ० } \\
& \text { ले० }
\end{aligned}
$$

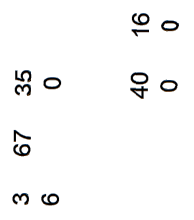

ก
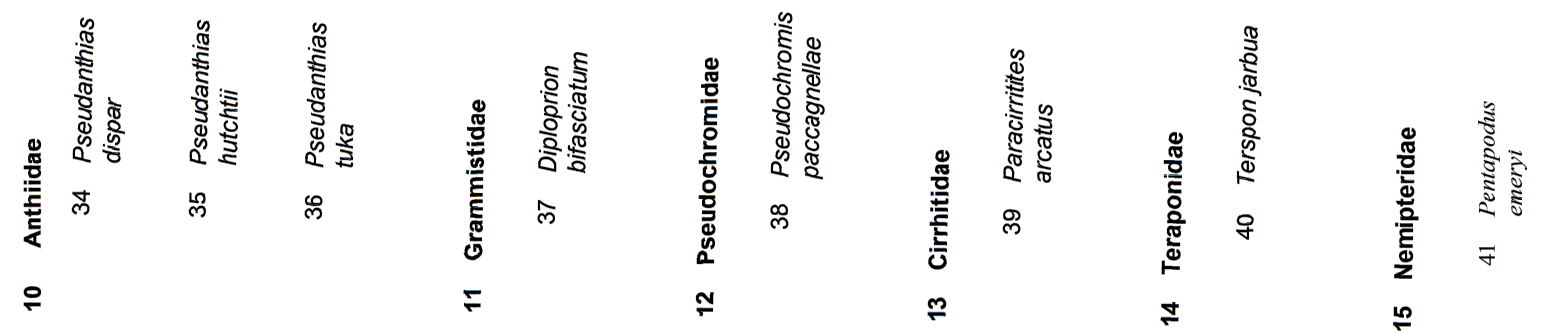
Sumber Daya Ikan Karang Perairan Kabupaten Banggai, Sulawesi Tengah (Saputro, G.B. \& Isa N.E.)

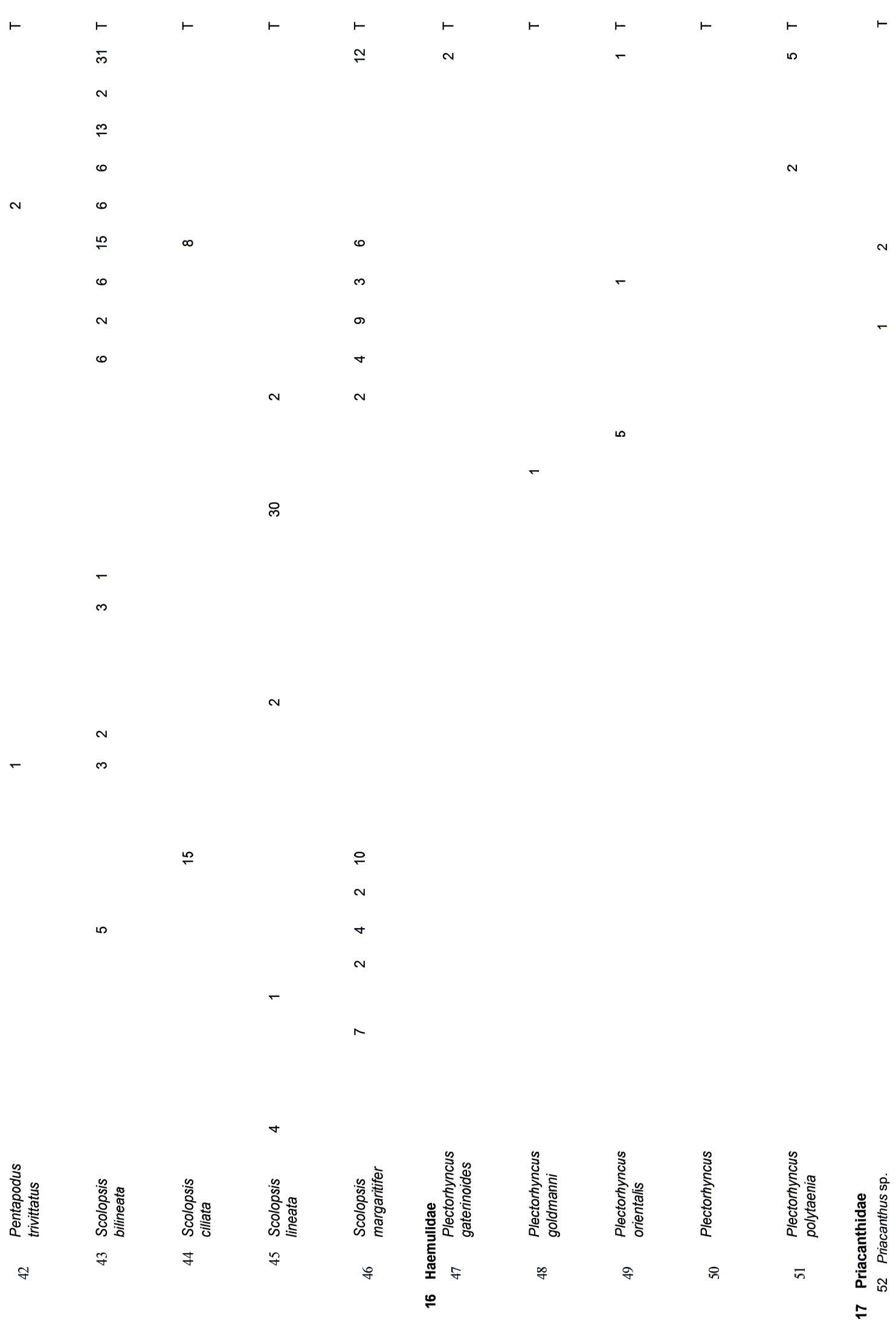




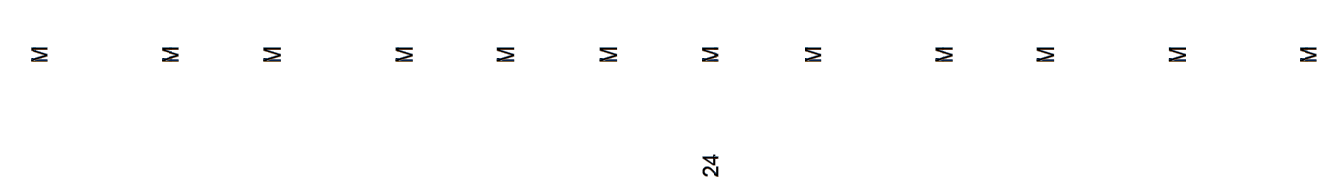

$\stackrel{N}{N}$

8

윰욤

R

ำ 은

$\simeq$

욤 喜

요

$\cong \quad \simeq$

ก

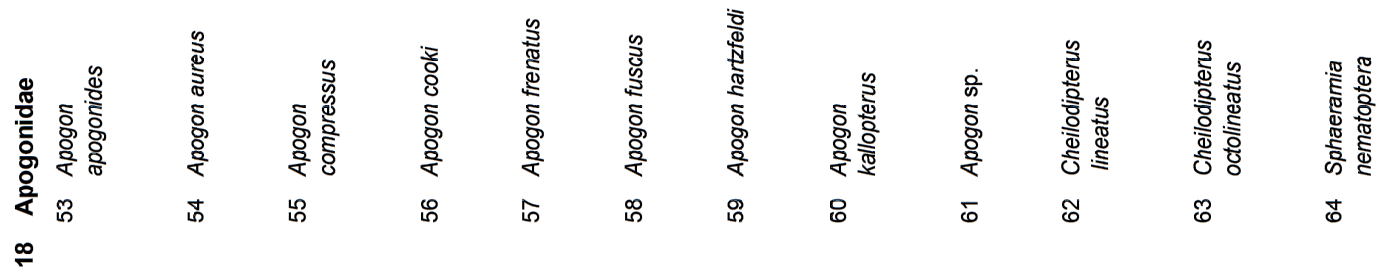


Sumber Daya Ikan Karang Perairan Kabupaten Banggai, Sulawesi Tengah (Saputro, G.B. \& Isa N.E.)

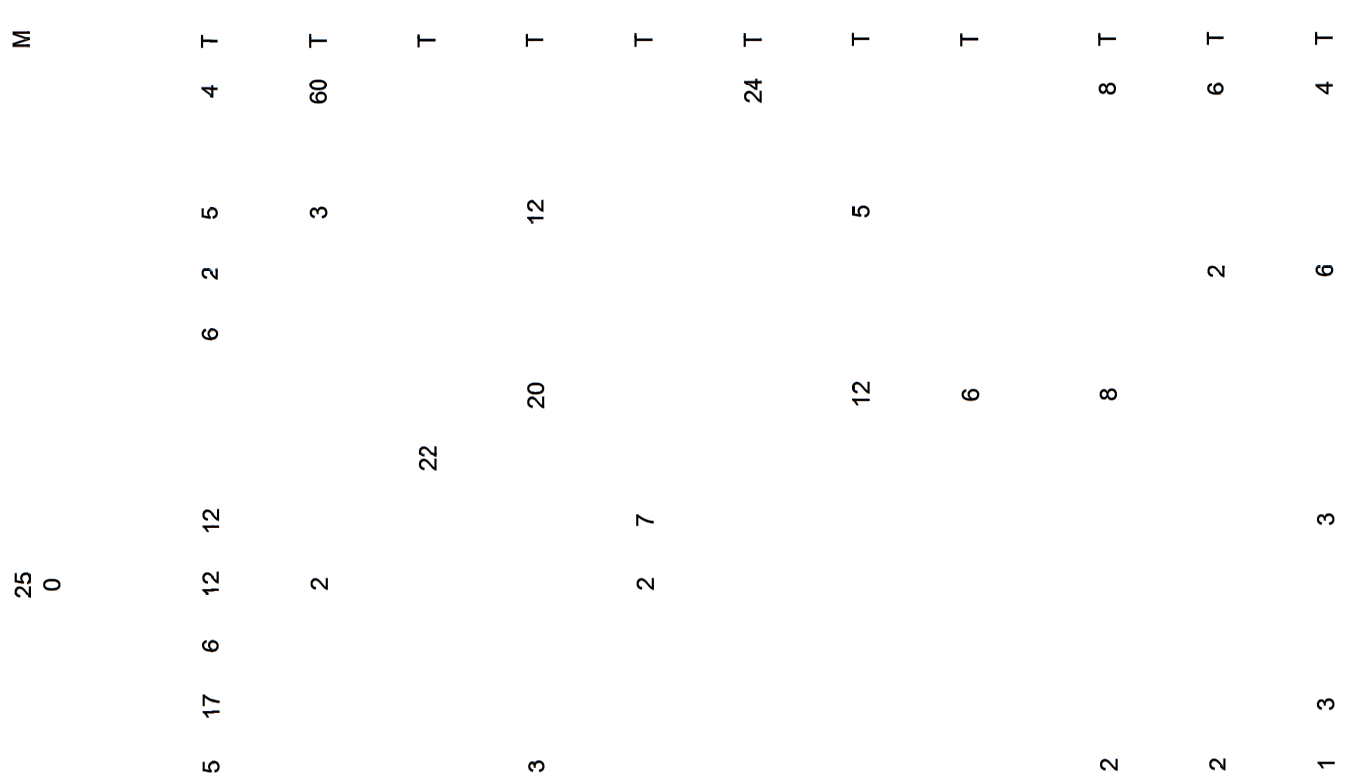

N

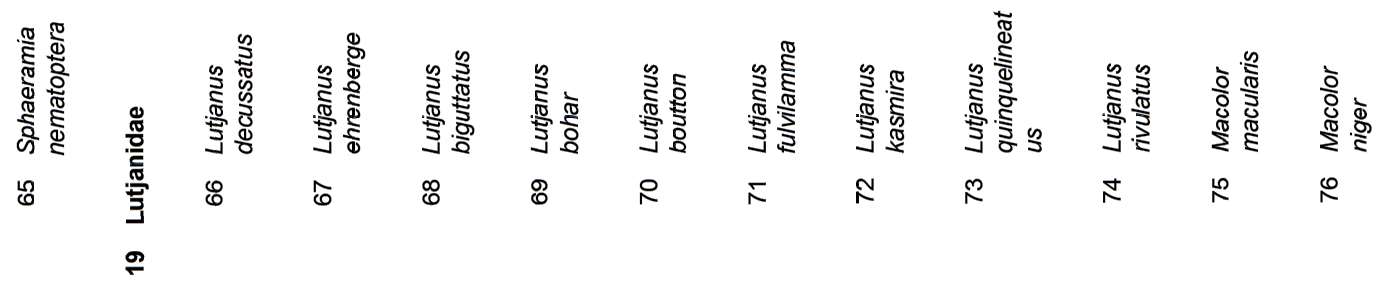




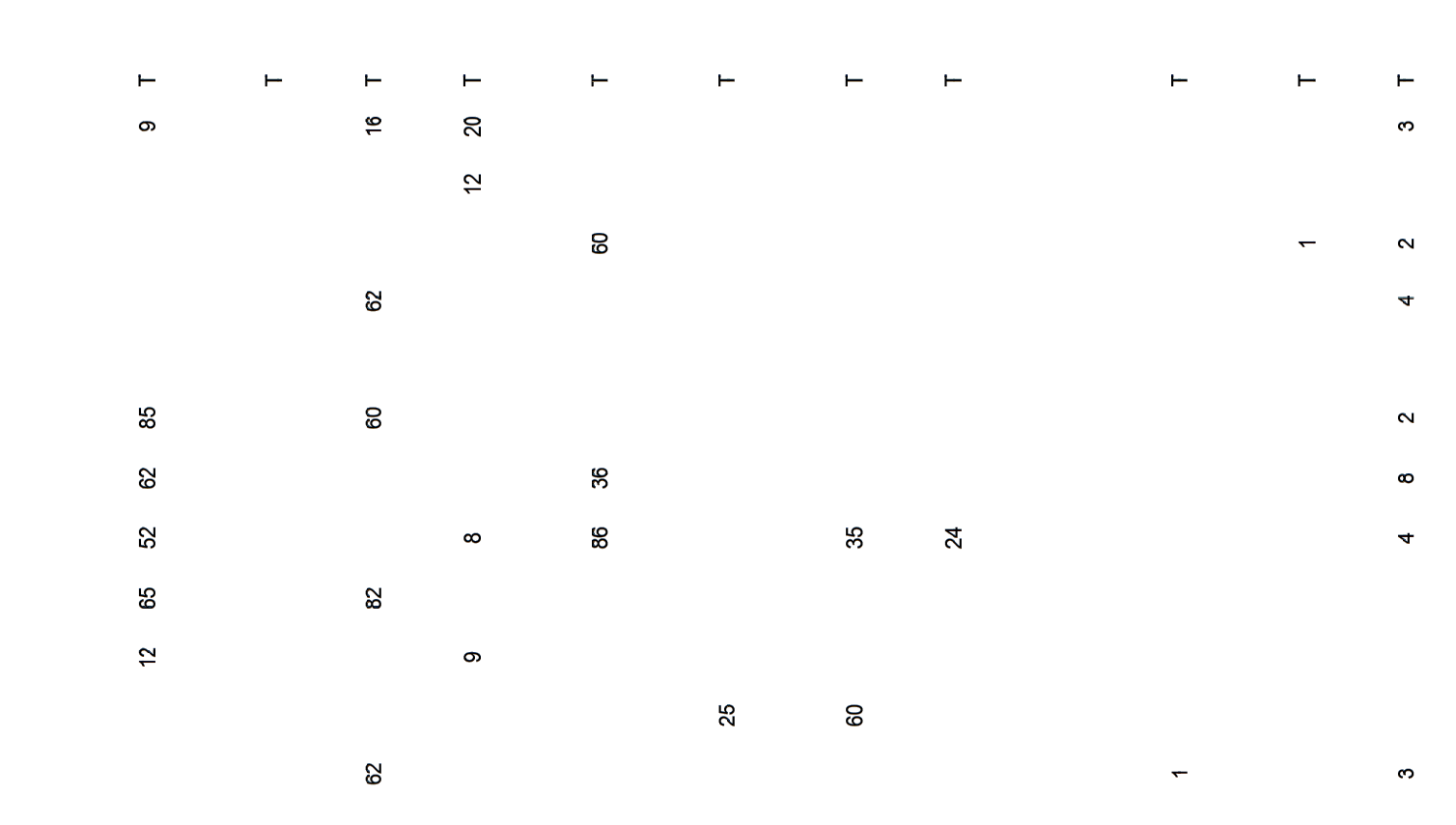
요 8
$\stackrel{5}{=}$

$\simeq$

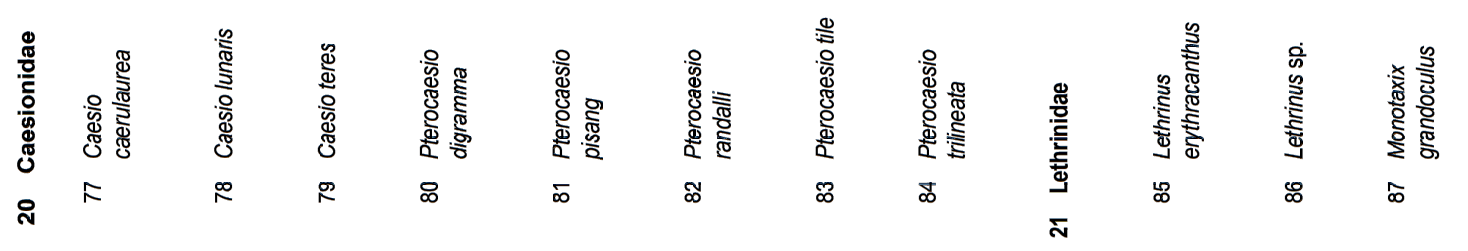


Sumber Daya Ikan Karang Perairan Kabupaten Banggai, Sulawesi Tengah (Saputro, G.B. \& Isa N.E.)
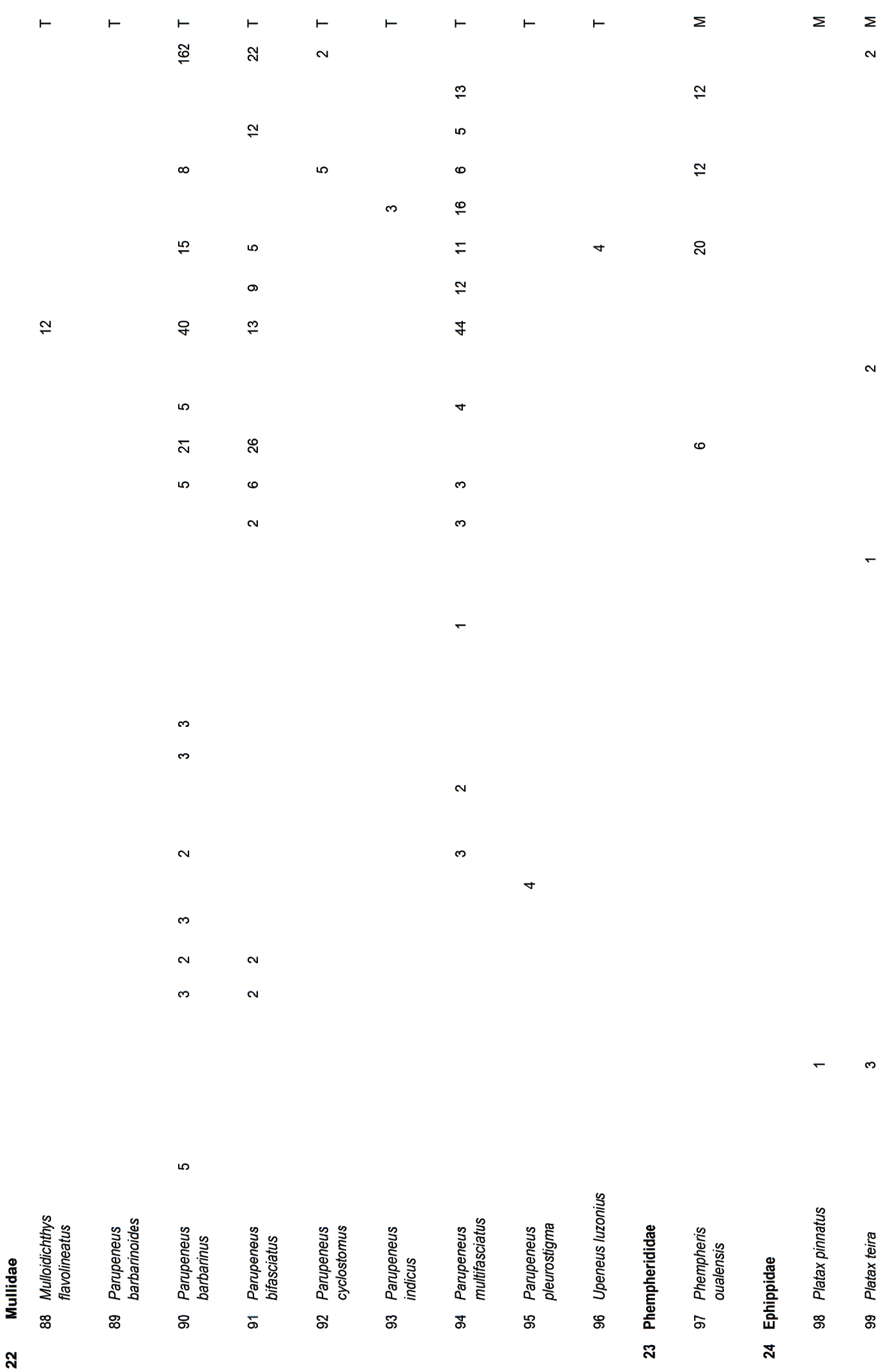


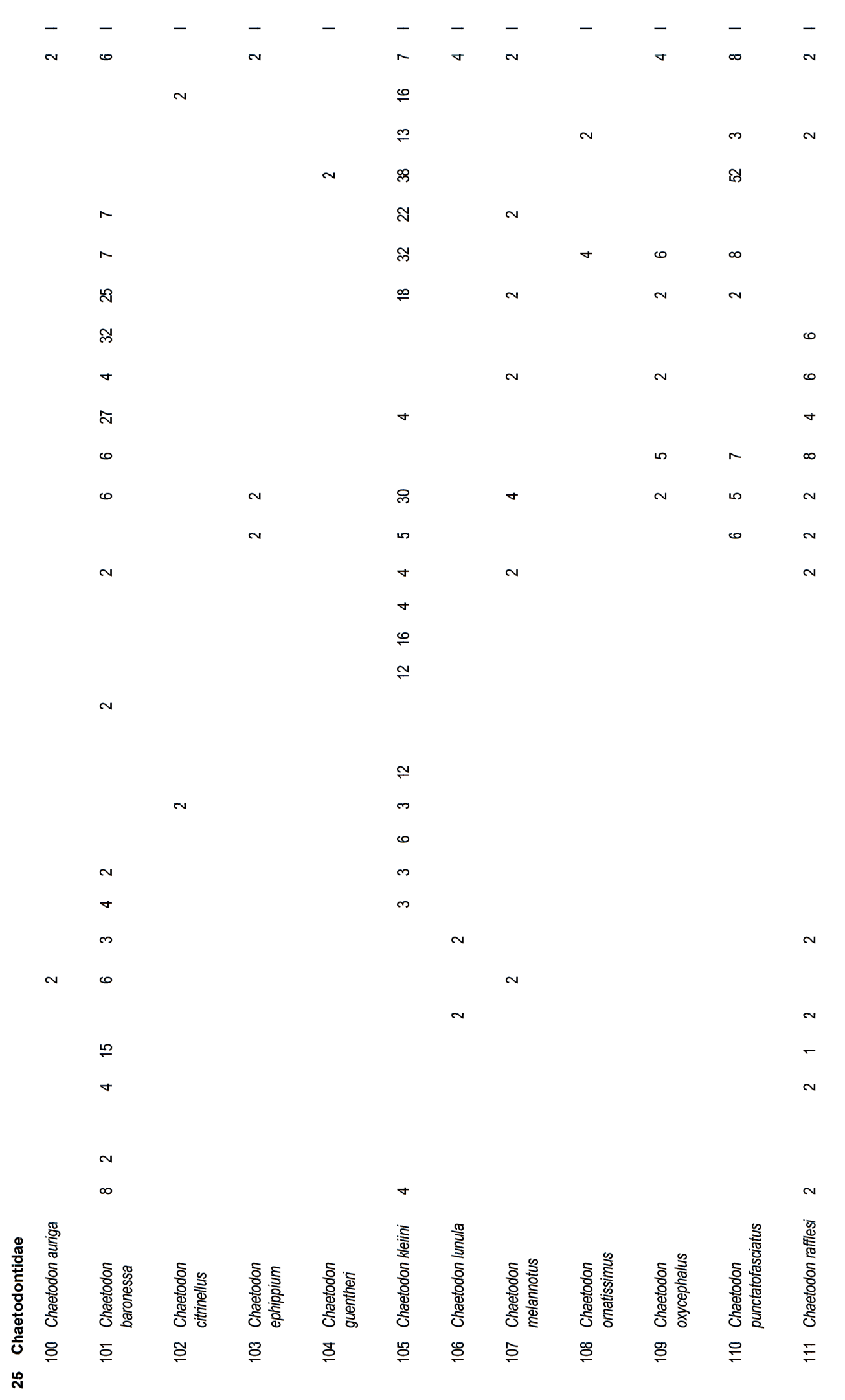


Sumber Daya Ikan Karang Perairan Kabupaten Banggai, Sulawesi Tengah (Saputro, G.B. \& Isa N.E.)

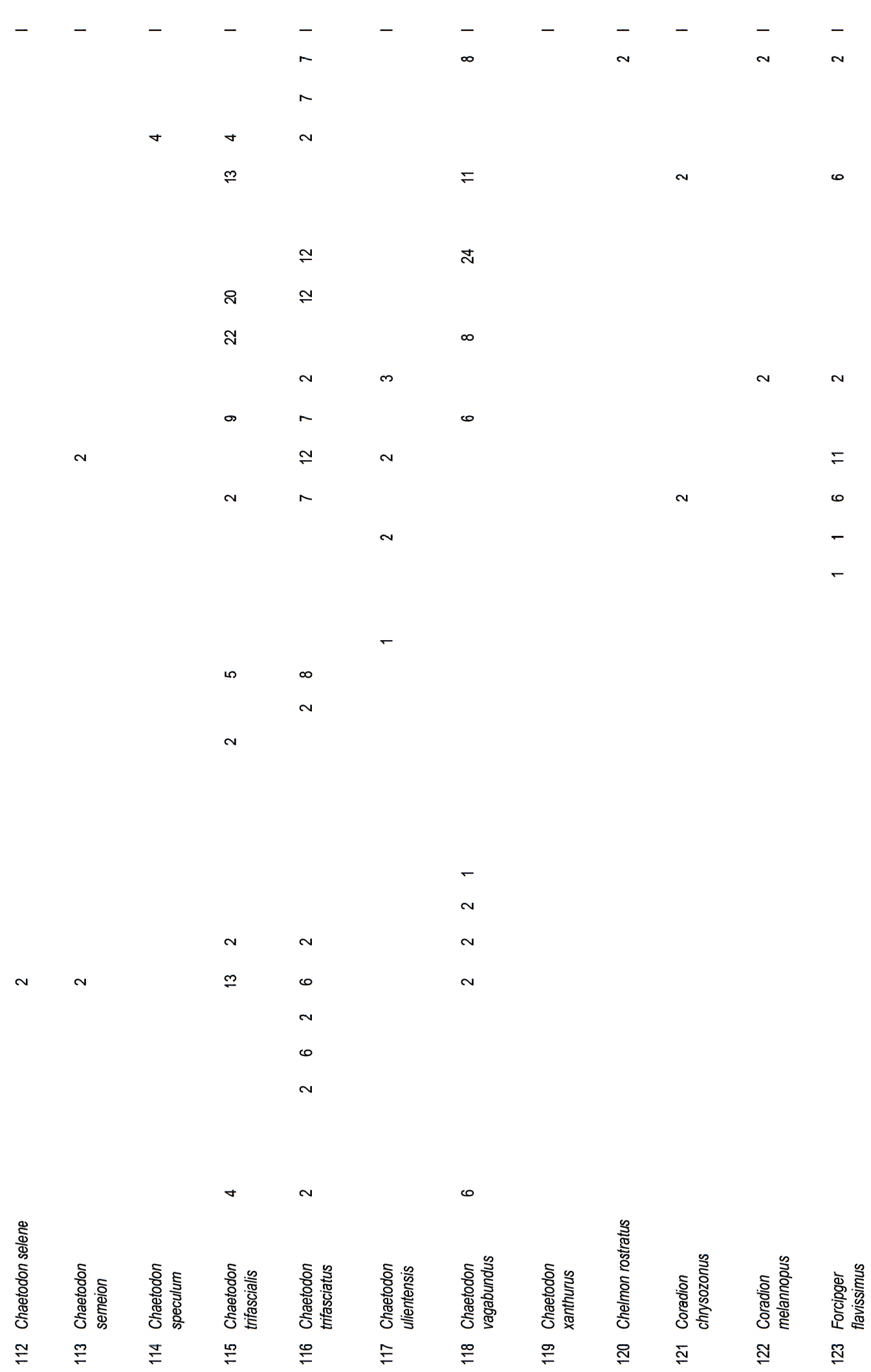



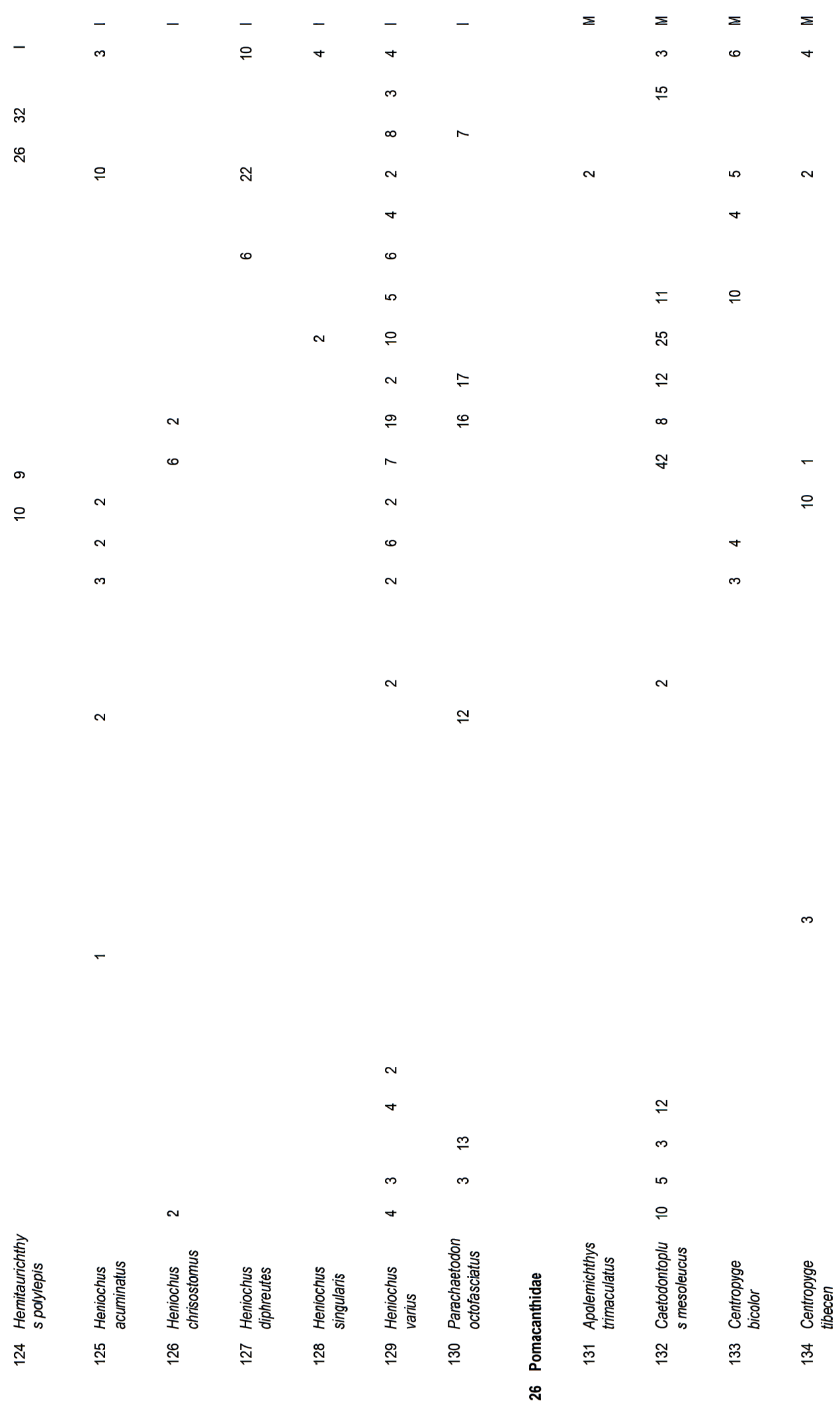
Sumber Daya Ikan Karang Perairan Kabupaten Banggai, Sulawesi Tengah (Saputro, G.B. \& Isa N.E.)

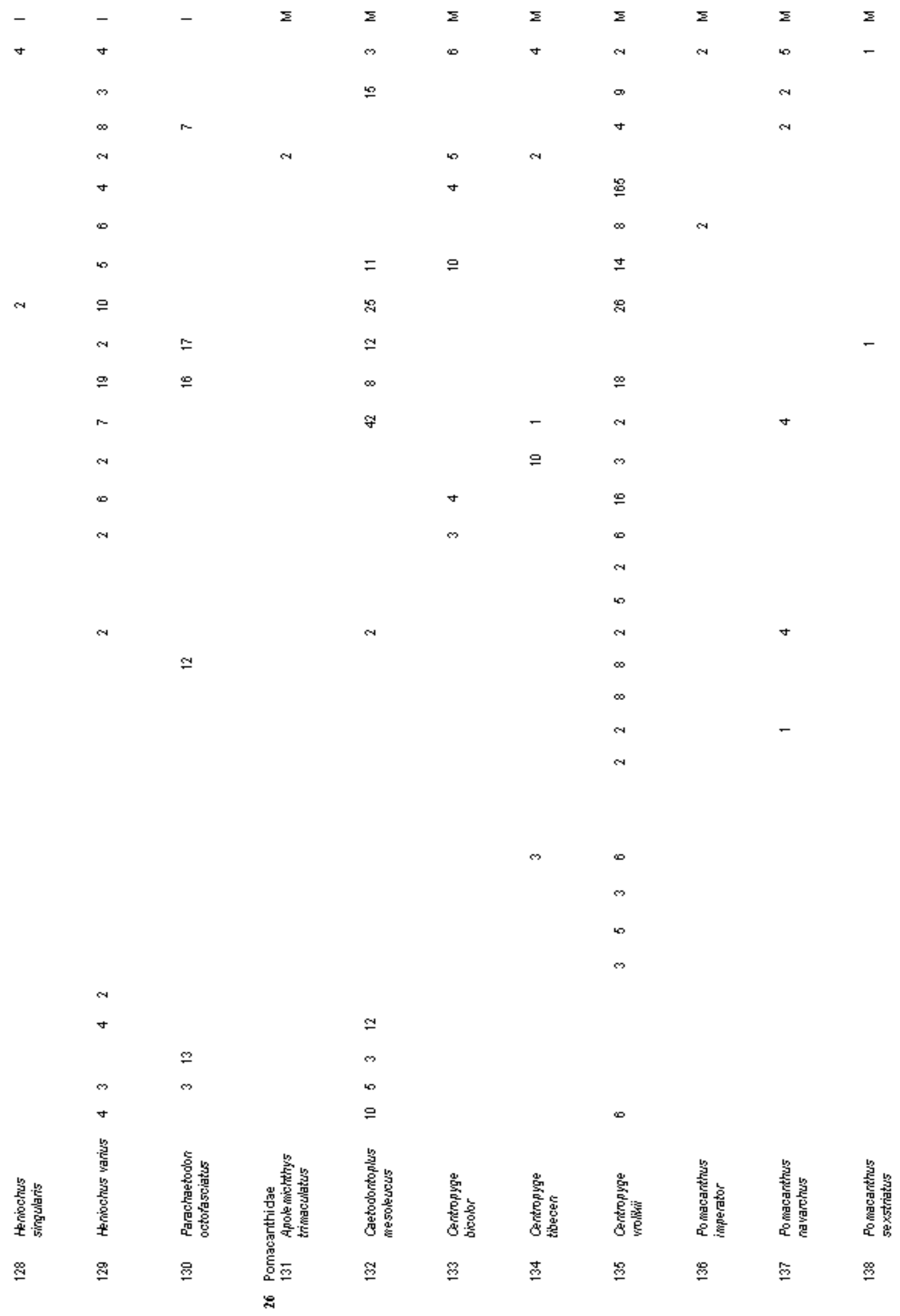




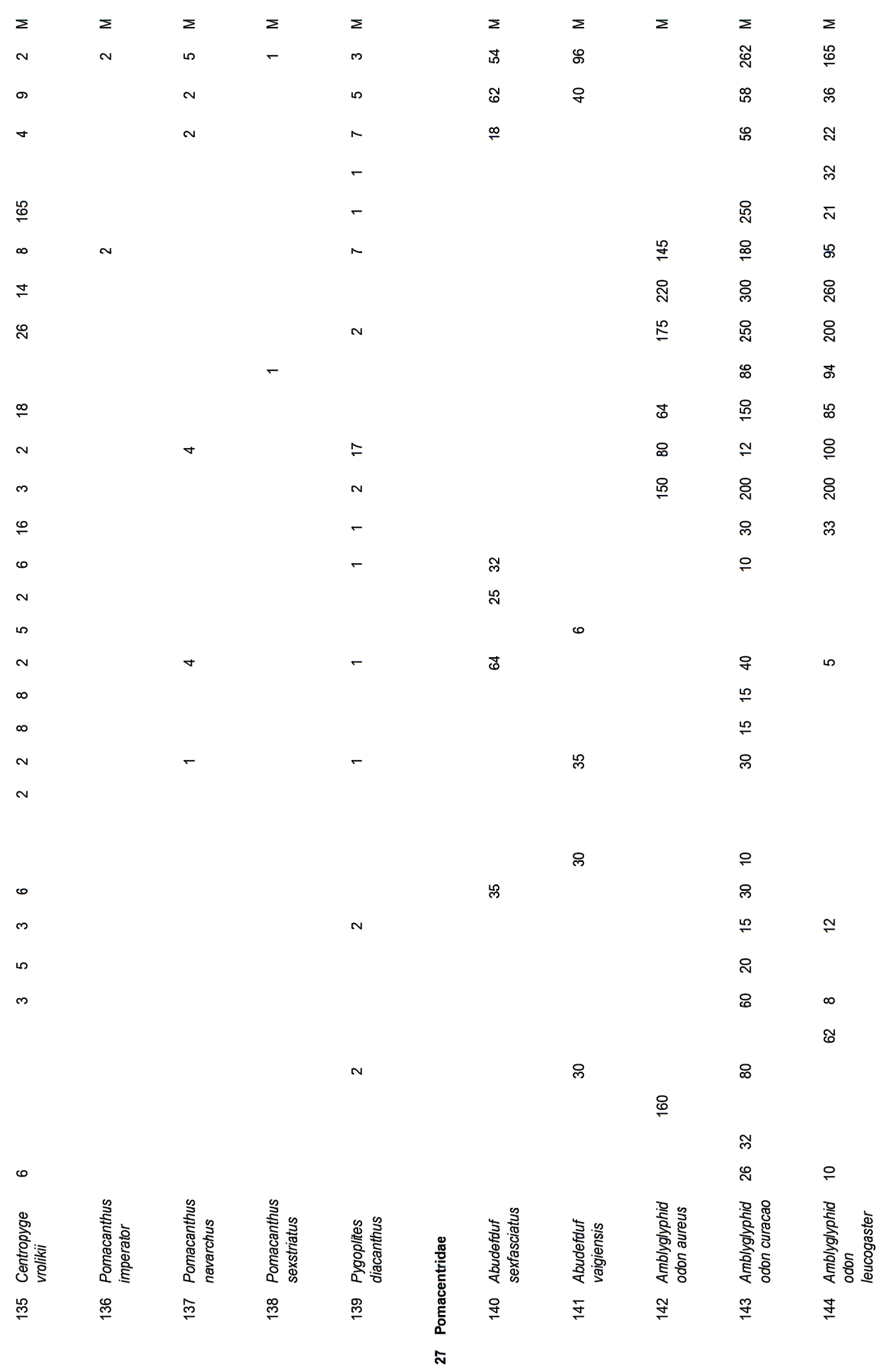


Sumber Daya Ikan Karang Perairan Kabupaten Banggai, Sulawesi Tengah (Saputro, G.B. \& Isa N.E.)

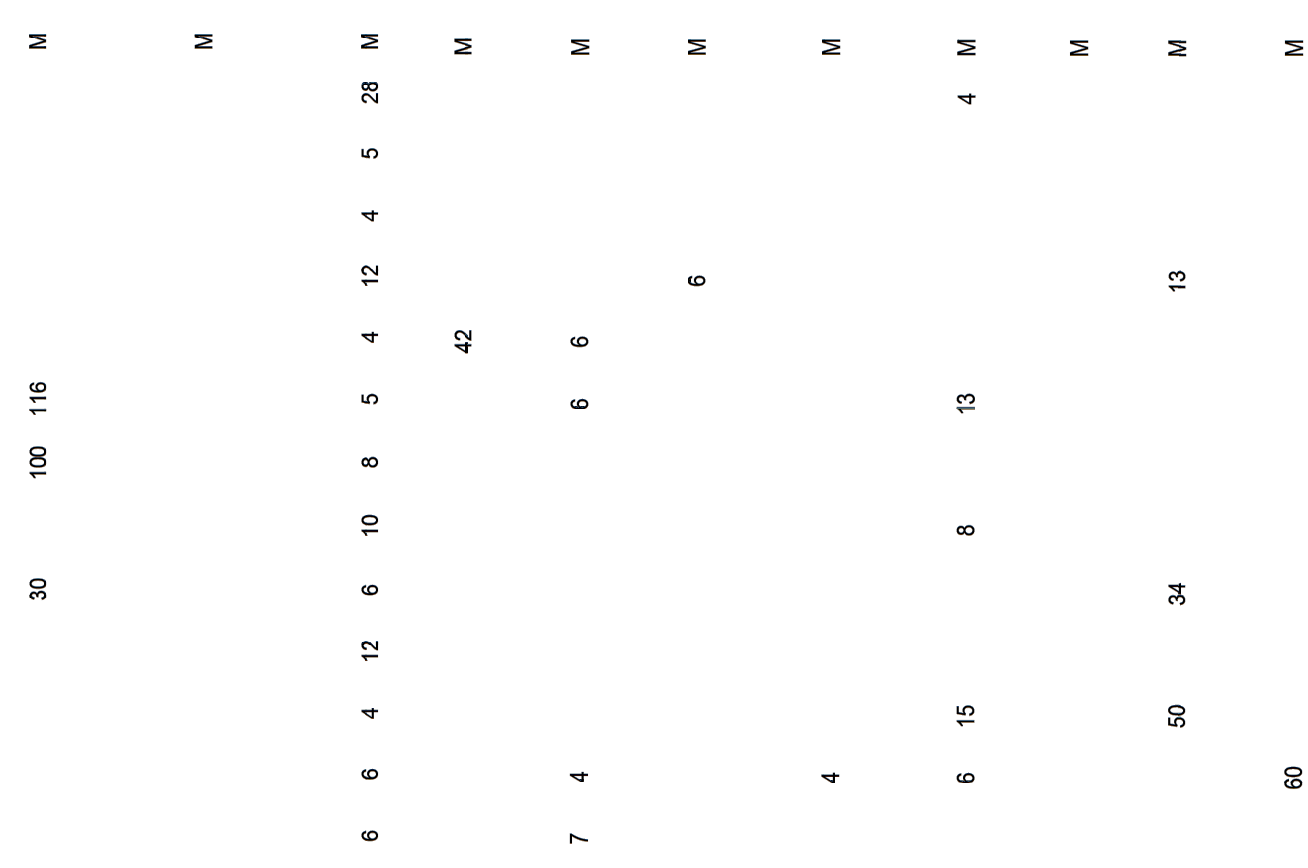

ล

$\circ$

N

เ

ลิ

N

เ

8

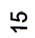

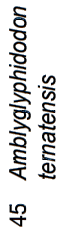

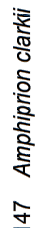
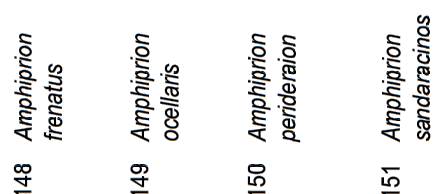

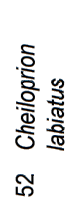

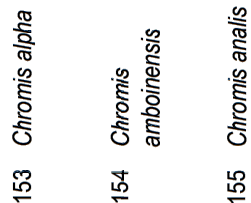



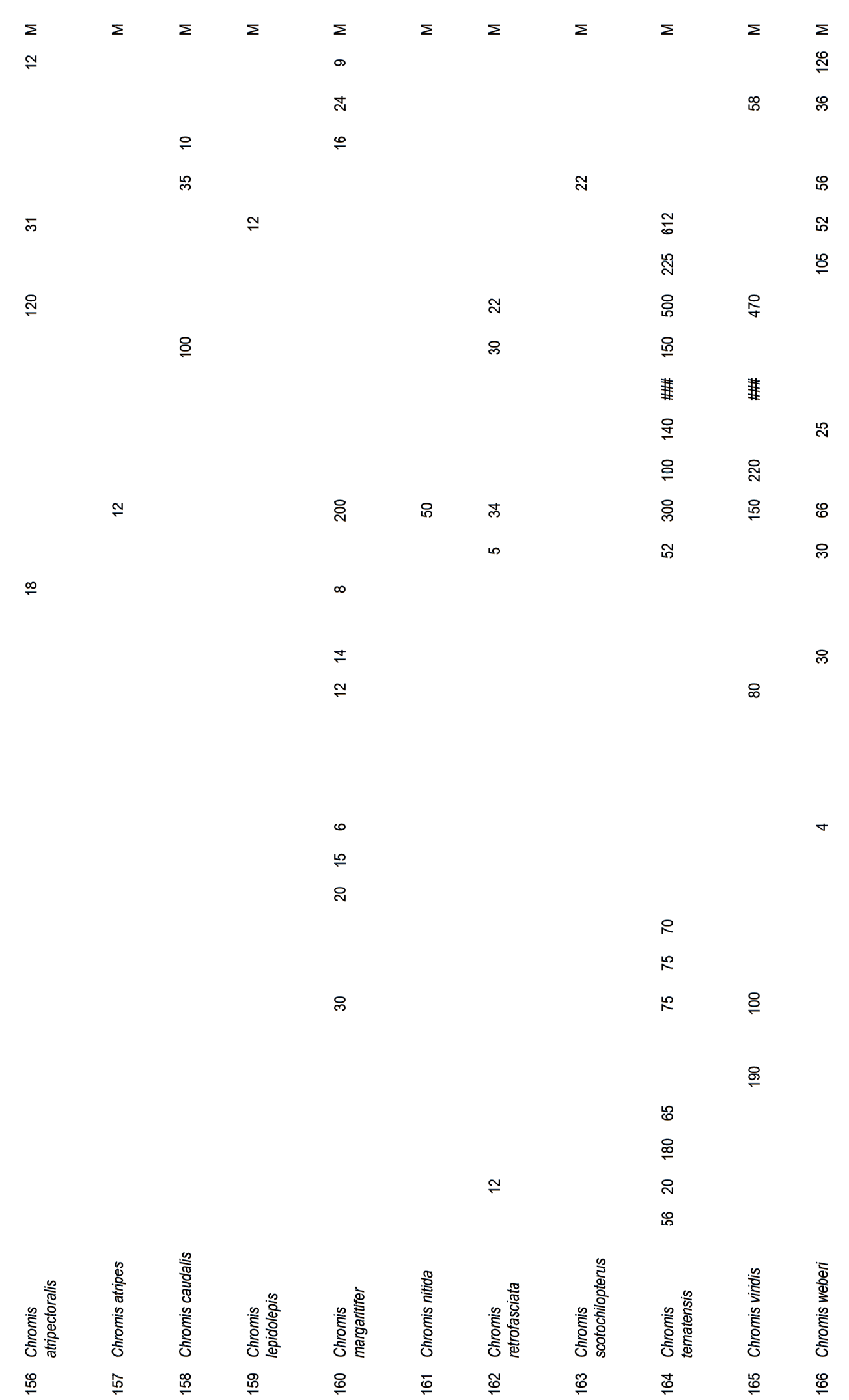
Sumber Daya Ikan Karang Perairan Kabupaten Banggai, Sulawesi Tengah (Saputro, G.B. \& Isa N.E.)

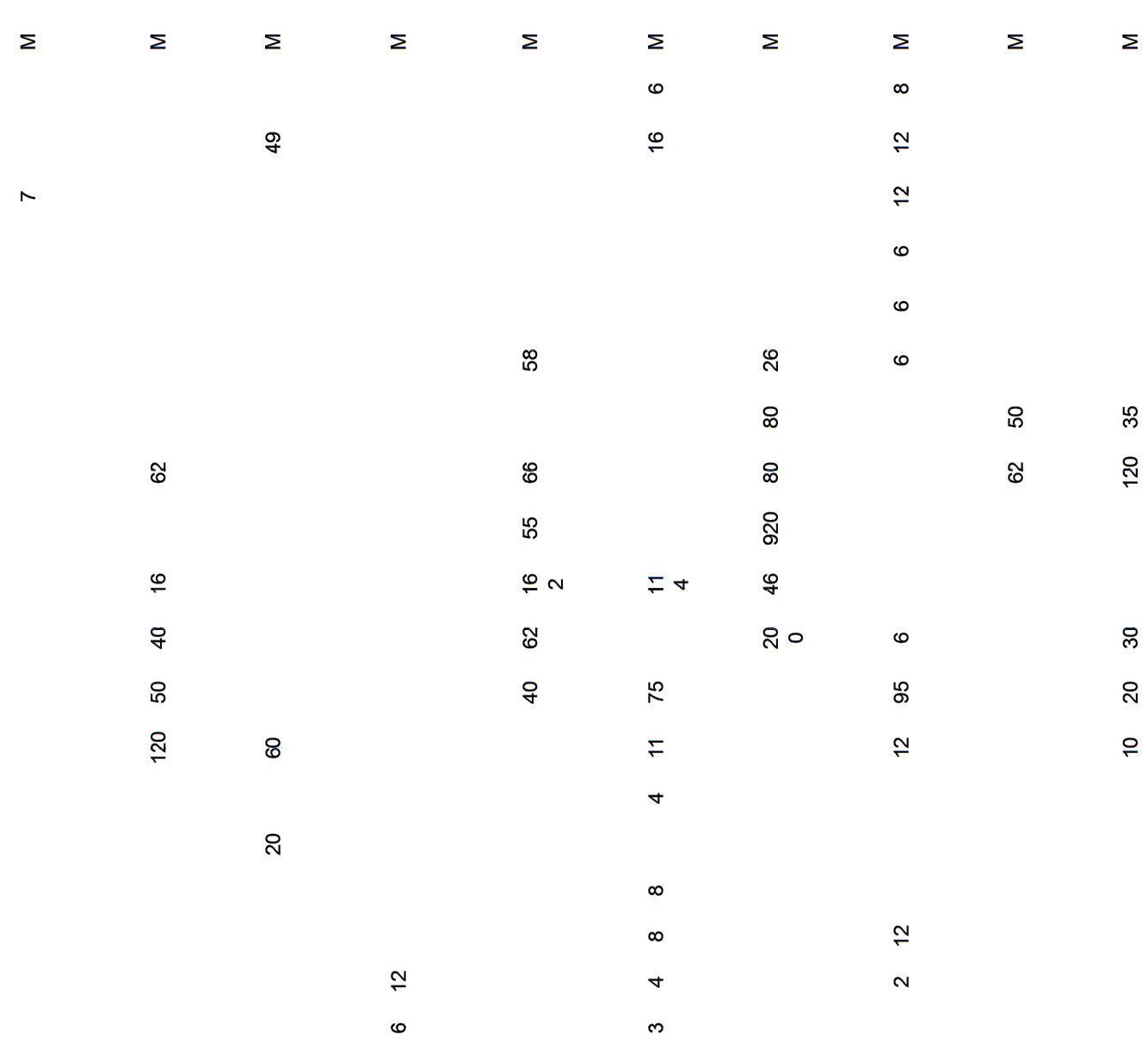

$\stackrel{\varphi}{\circ}$

$\stackrel{8}{\circ}$

$\stackrel{\circ}{\circ} \stackrel{\circ}{\circ}$

$\stackrel{ }{N}$

은 $\quad \stackrel{\text { ก }}{2}$

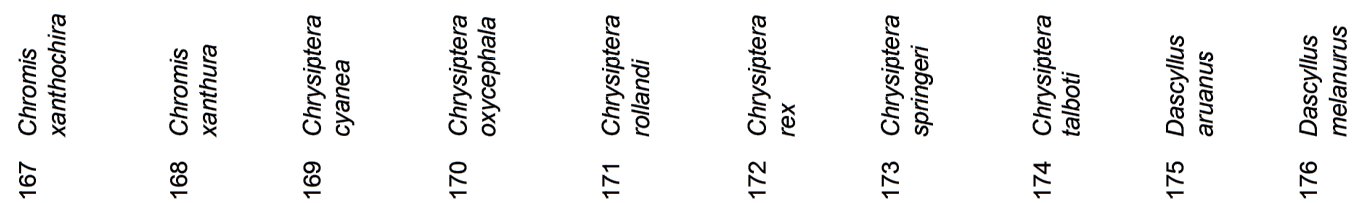



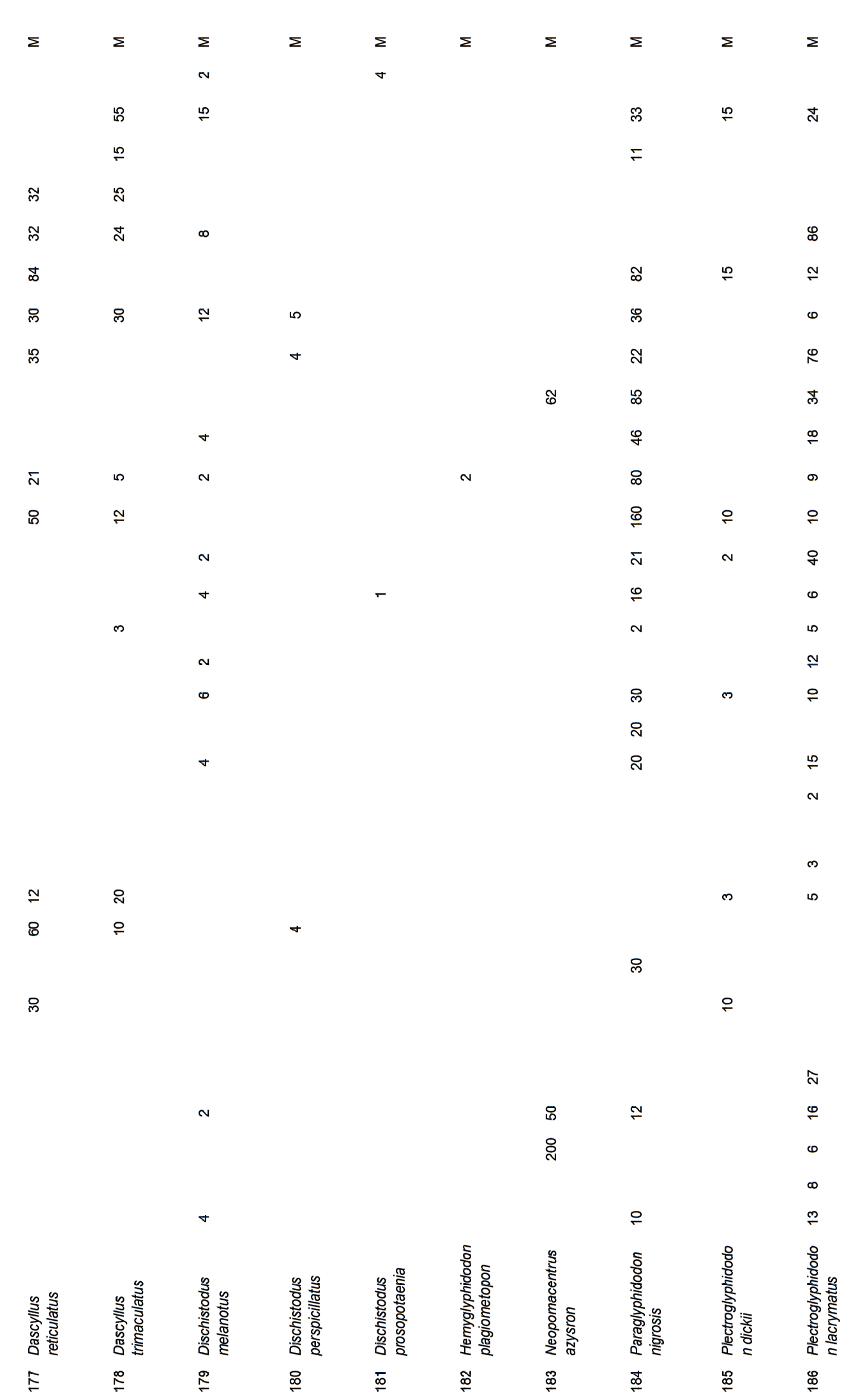
Sumber Daya Ikan Karang Perairan Kabupaten Banggai, Sulawesi Tengah (Saputro, G.B. \& Isa N.E.)
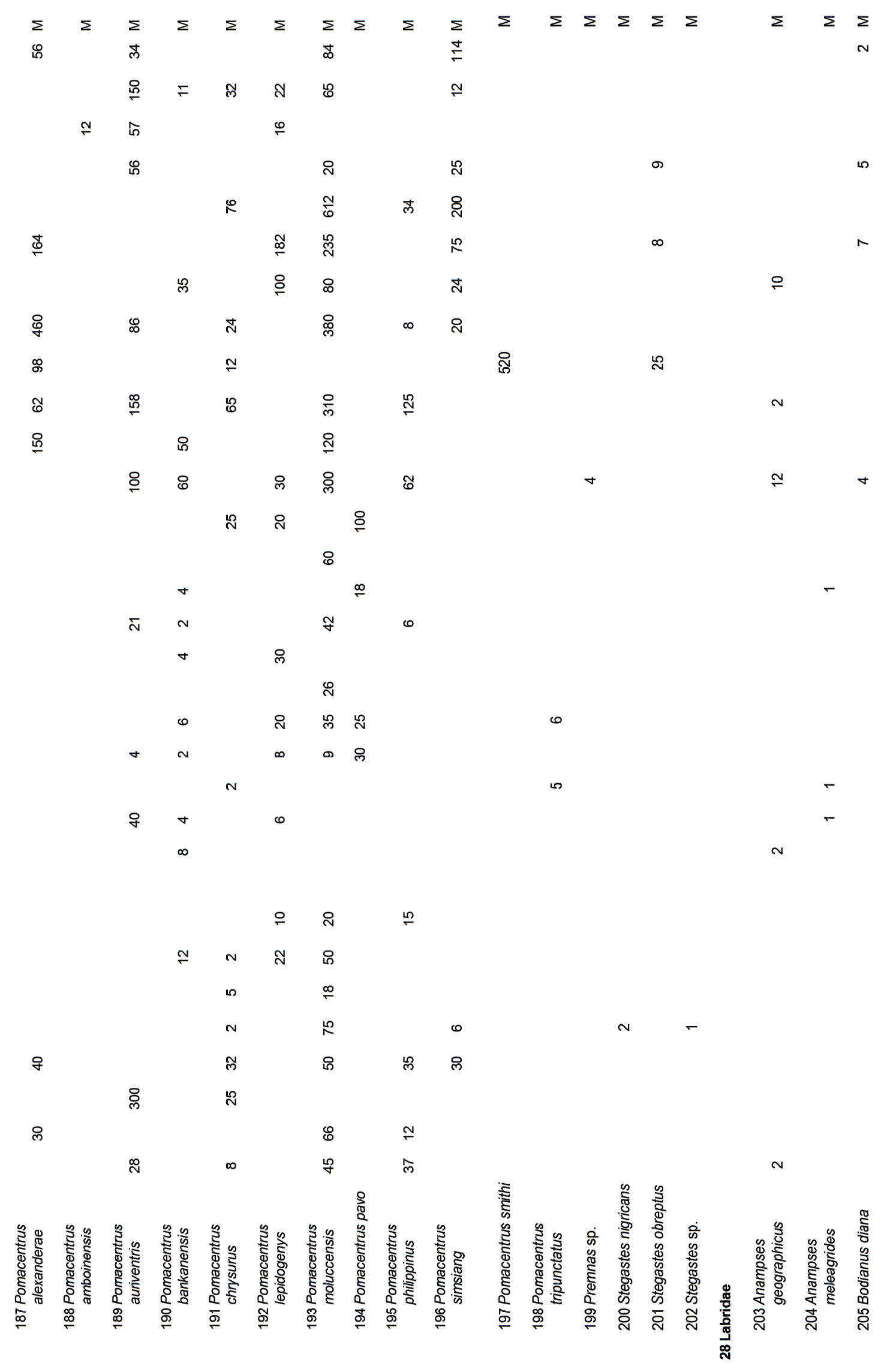

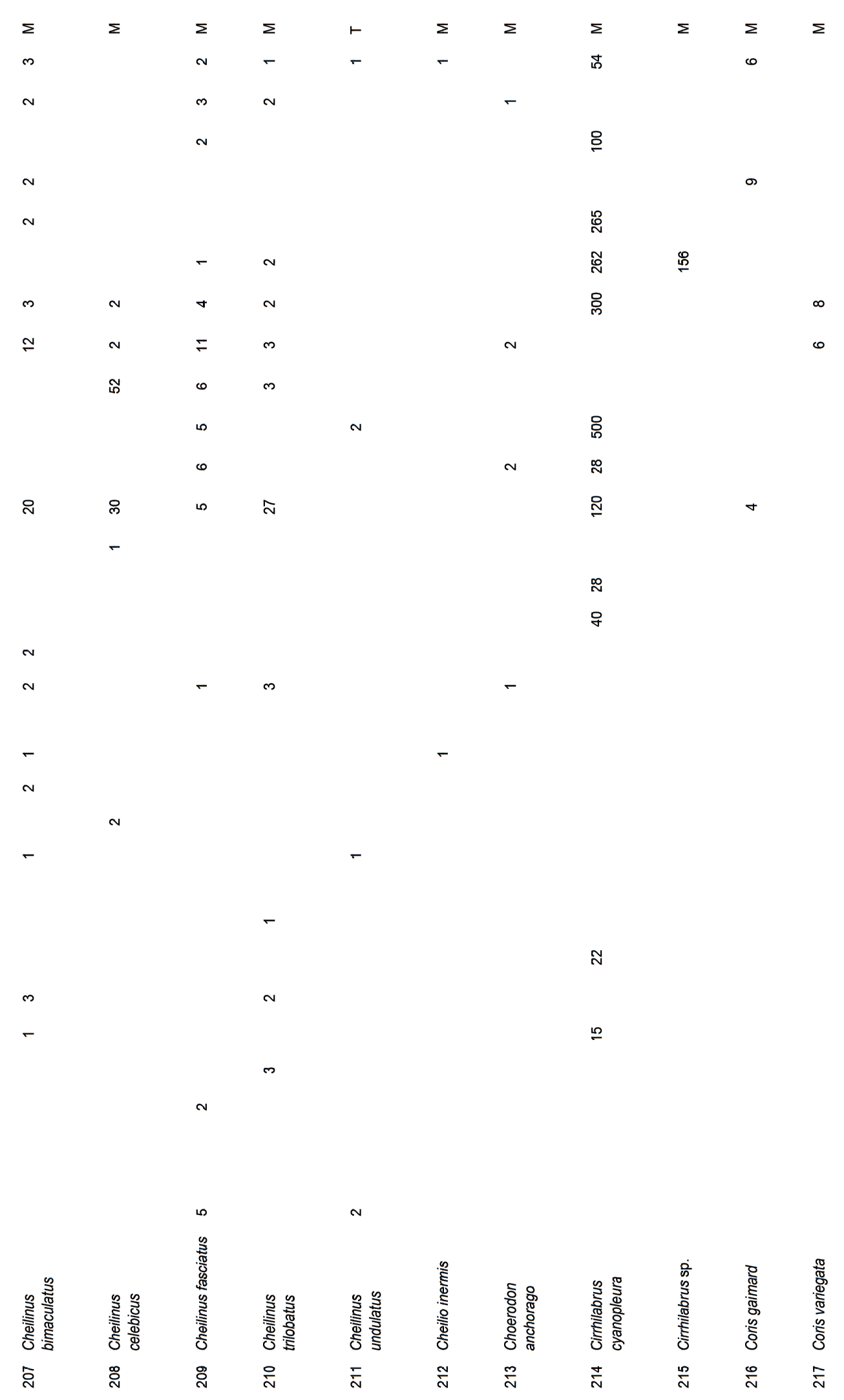
Sumber Daya Ikan Karang Perairan Kabupaten Banggai, Sulawesi Tengah (Saputro, G.B. \& Isa N.E.)

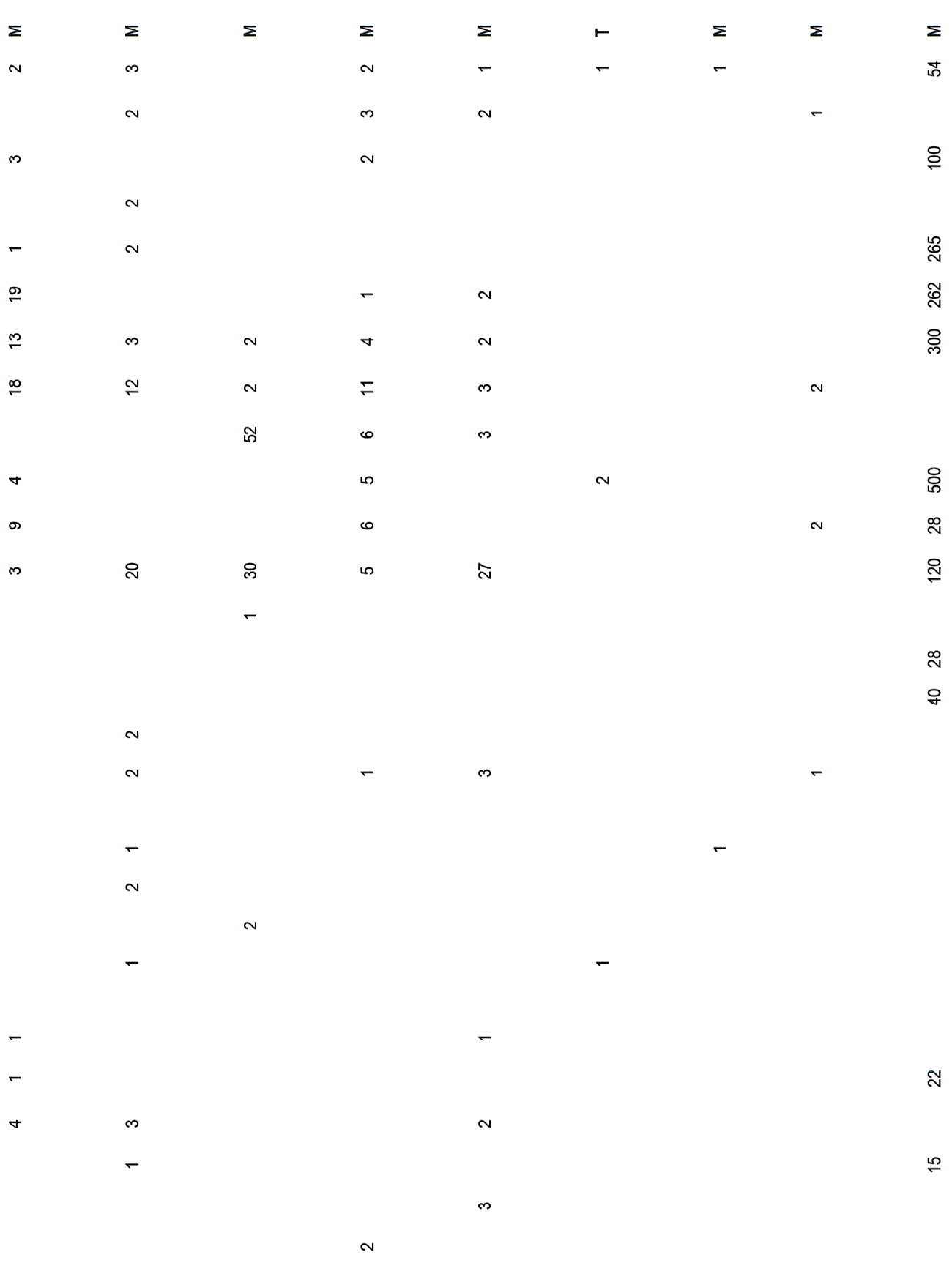

เ

N

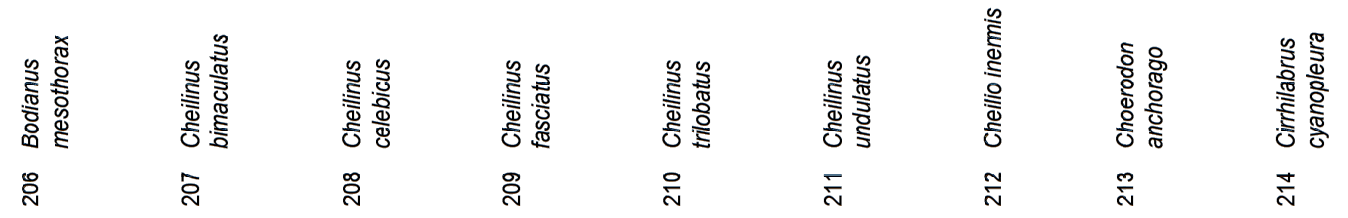




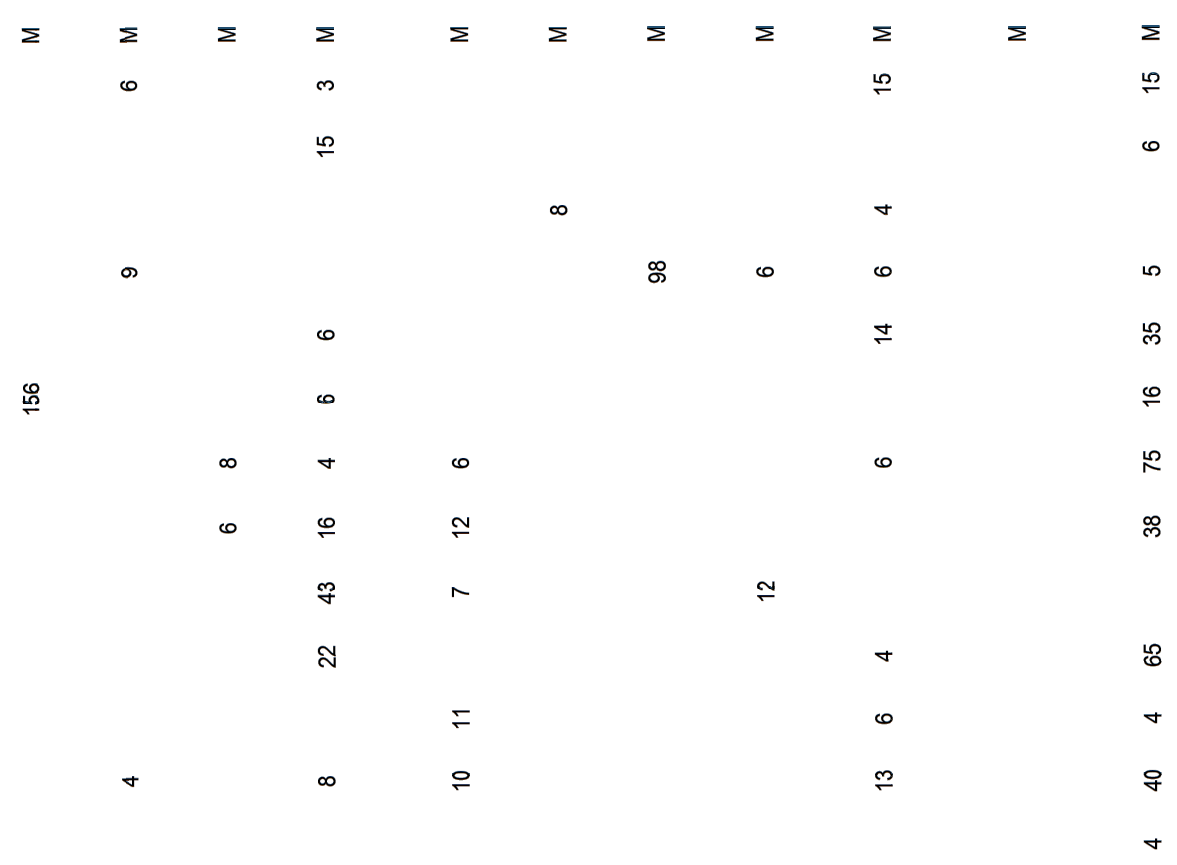

N

$\circ$

N

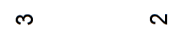

$-$

N

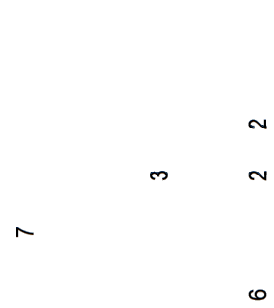

N

$m$

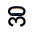

N

๑

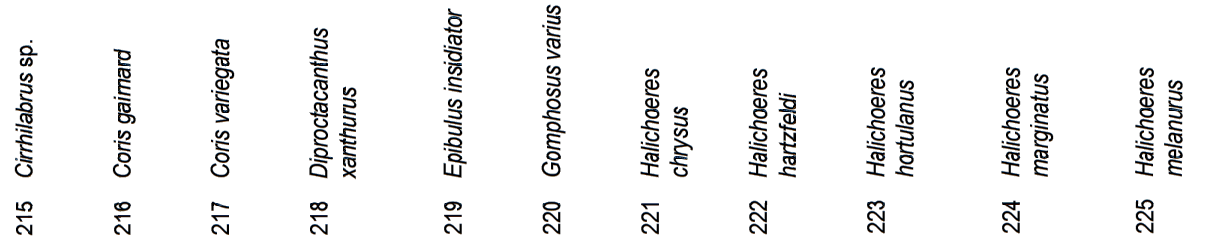


Sumber Daya Ikan Karang Perairan Kabupaten Banggai, Sulawesi Tengah (Saputro, G.B. \& Isa N.E.)

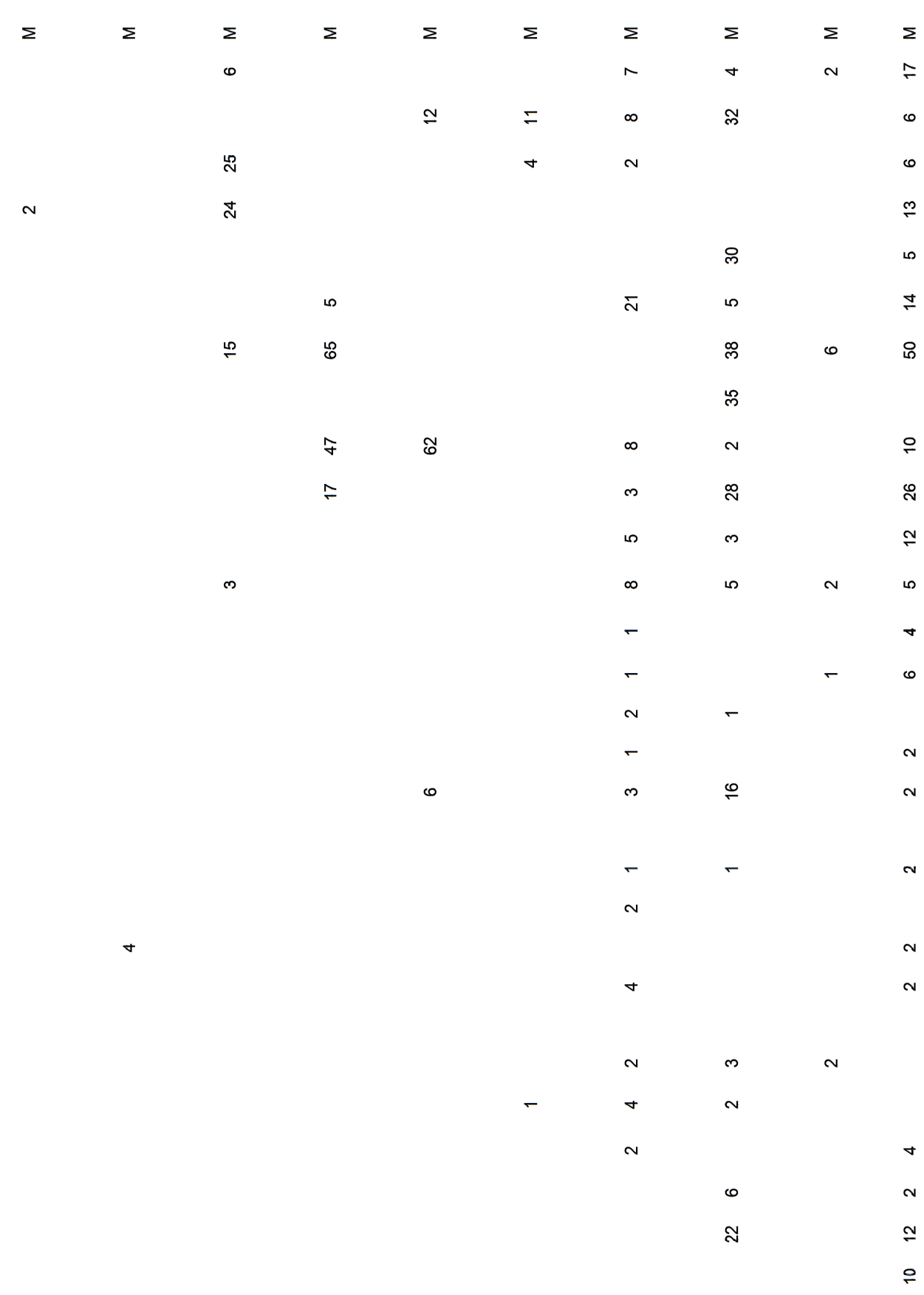

N

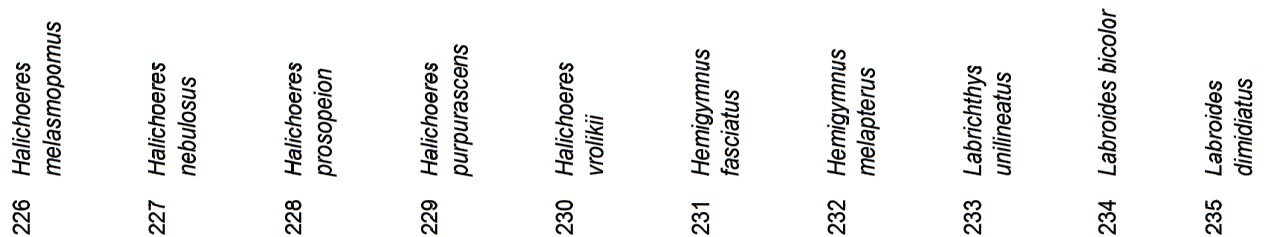




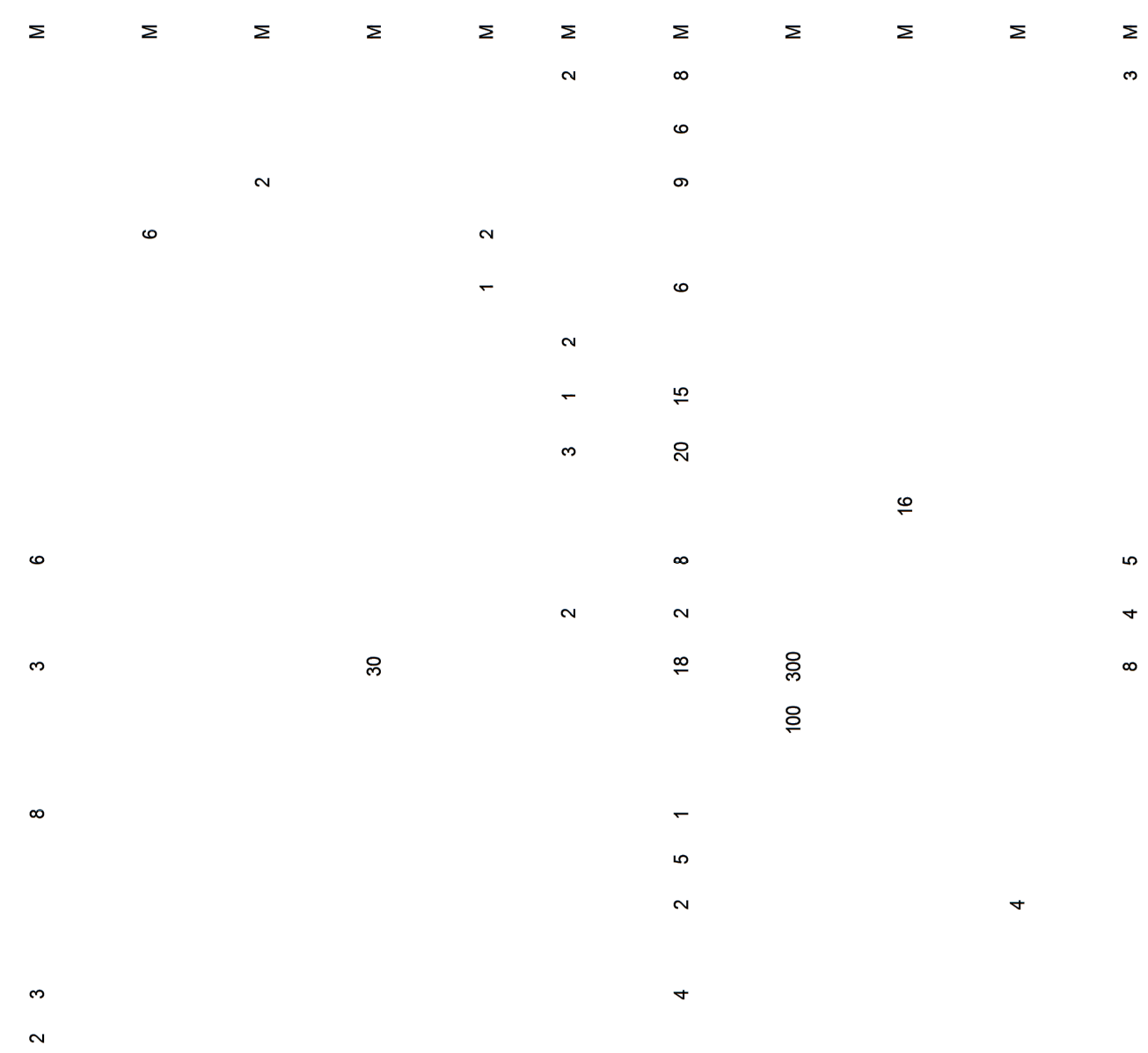

우

우

$\sim$

m

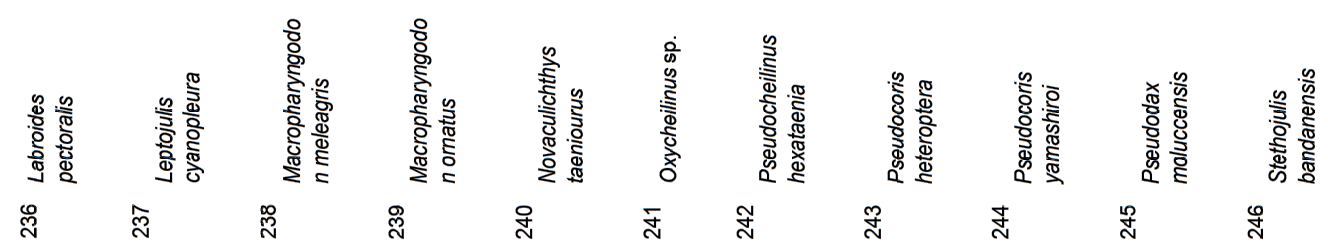


Sumber Daya Ikan Karang Perairan Kabupaten Banggai, Sulawesi Tengah (Saputro, G.B. \& Isa N.E.)

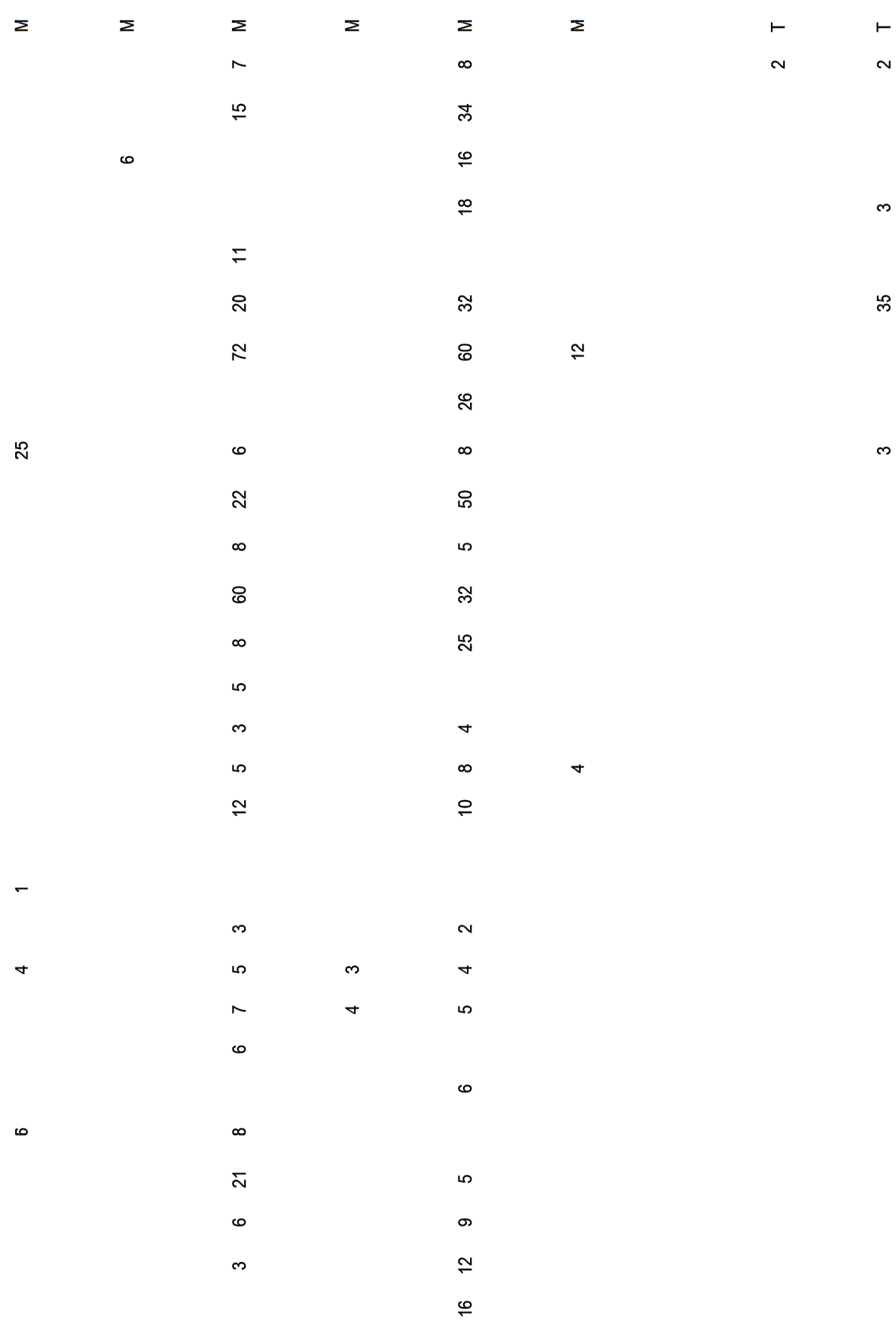

๑

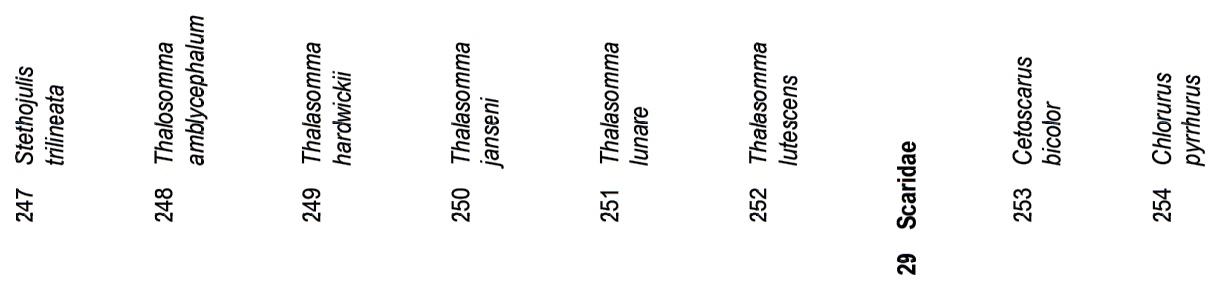




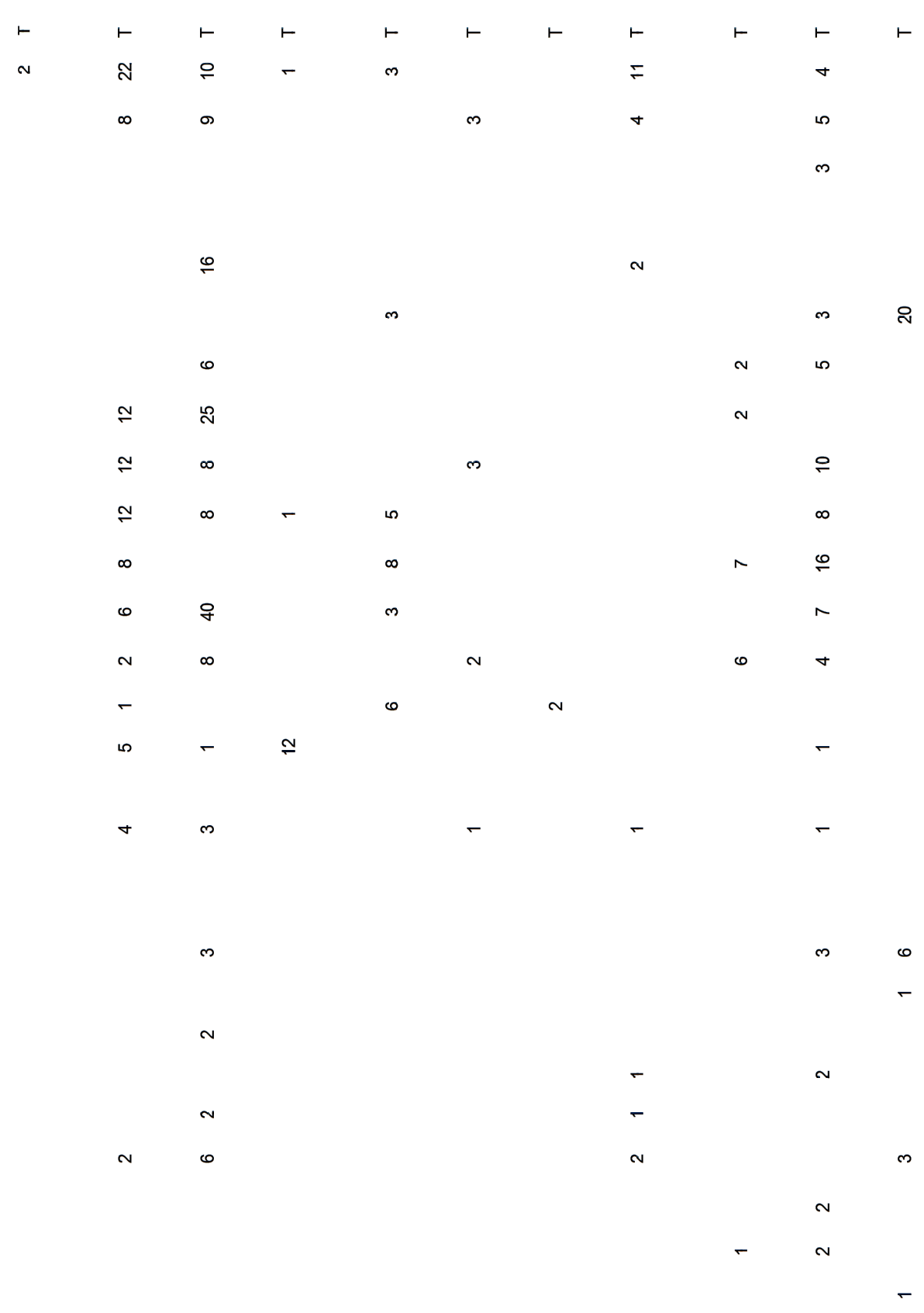

$\infty \quad$ N

N

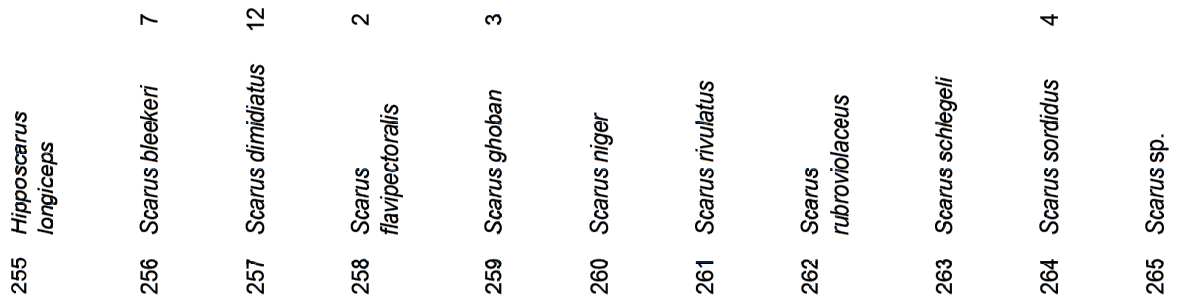


Sumber Daya Ikan Karang Perairan Kabupaten Banggai, Sulawesi Tengah (Saputro, G.B. \& Isa N.E.)

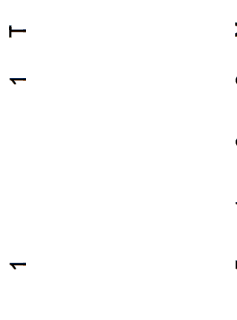

$\Sigma$

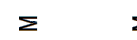

$\Sigma$

N

10

เ

$m$

$\infty$

$\wedge$

N

오

v

$\stackrel{5}{\circ}$

N

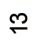

$N$

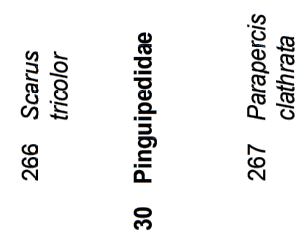

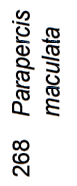

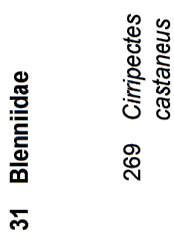

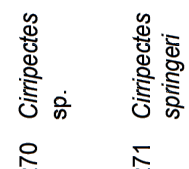

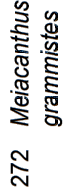




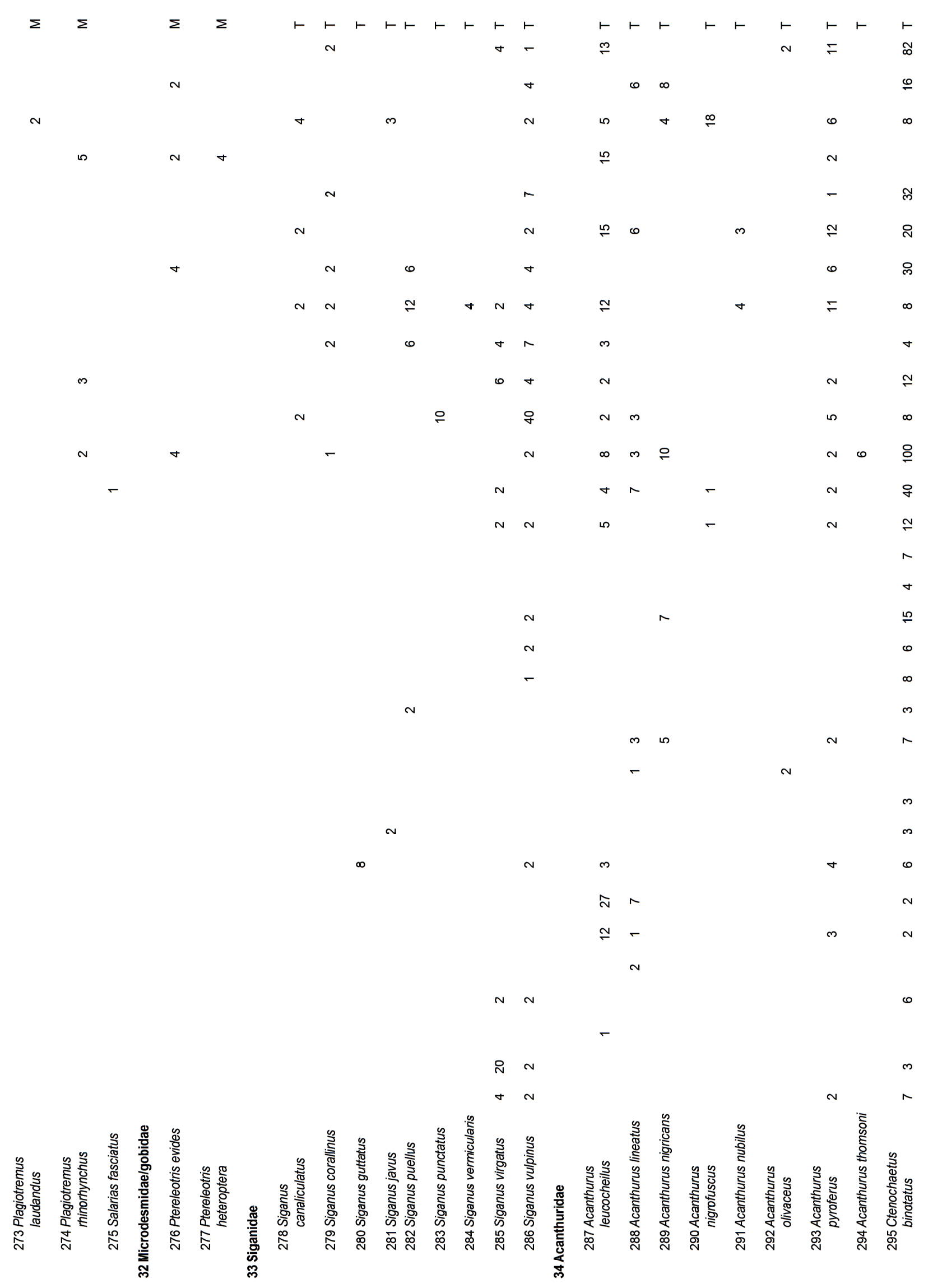


Sumber Daya Ikan Karang Perairan Kabupaten Banggai, Sulawesi Tengah (Saputro, G.B. \& Isa N.E.)

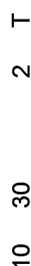

N

$\stackrel{F}{\sim}$

유

$\stackrel{\circ}{\circ}$

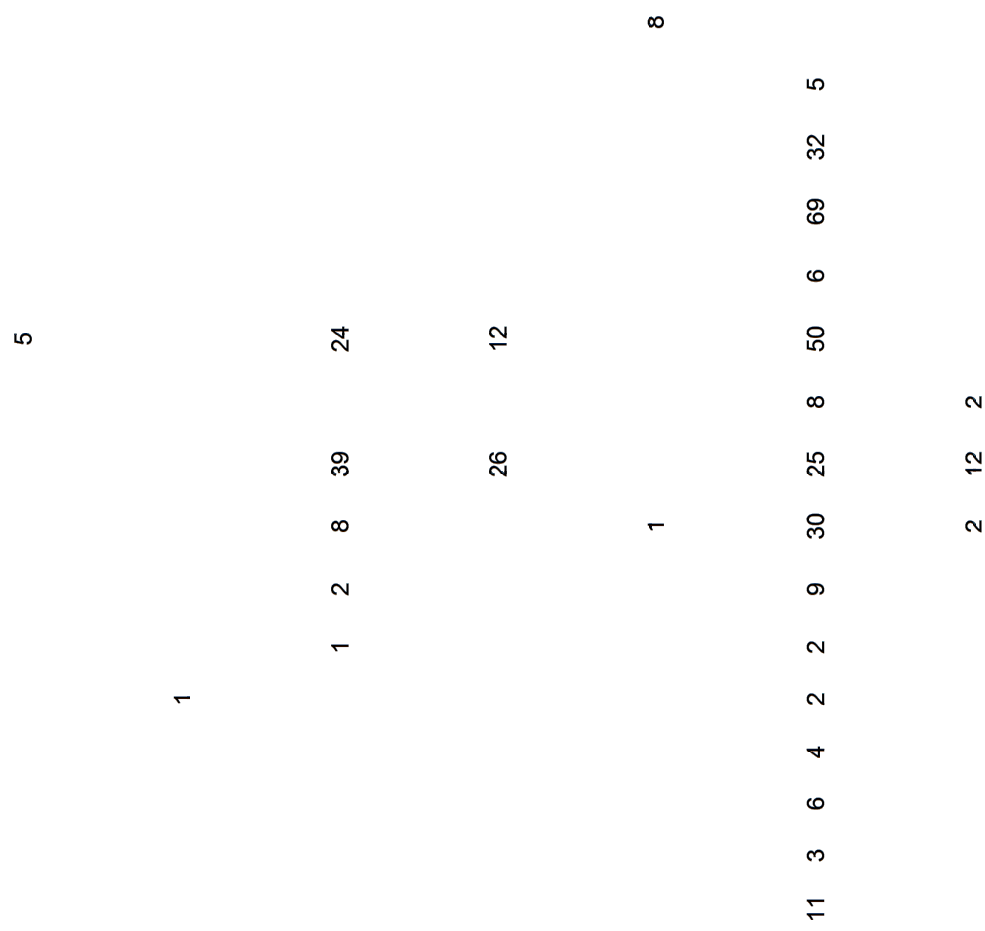

N

o

$m$

$\bullet$

$\bullet$

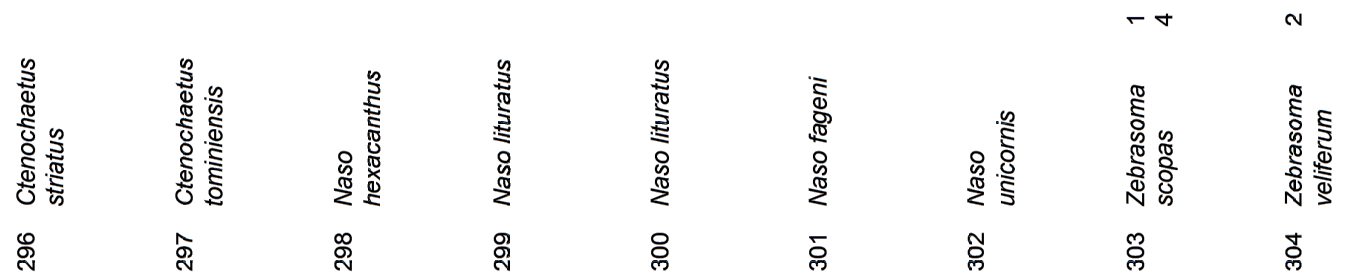




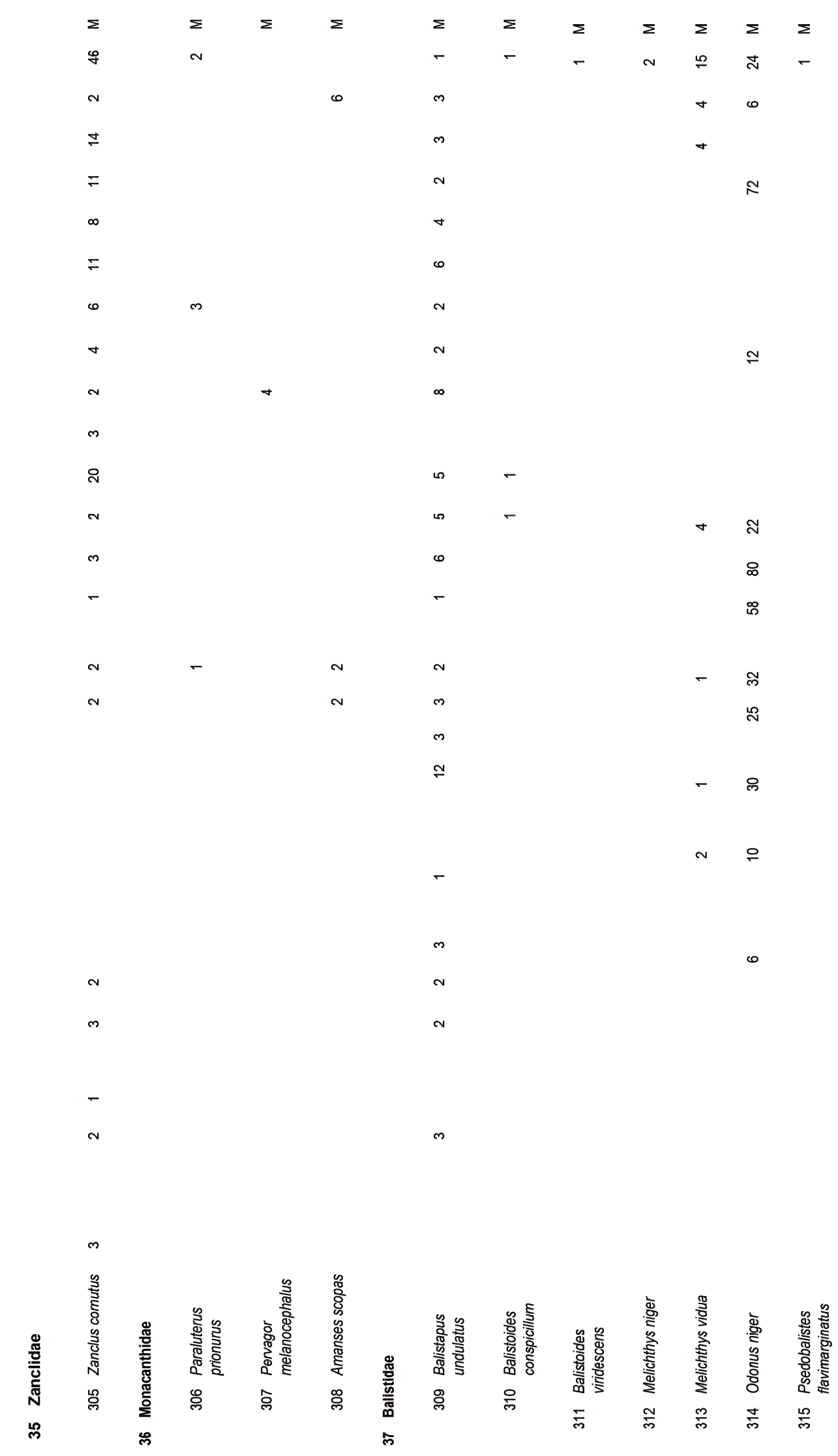


Sumber Daya Ikan Karang Perairan Kabupaten Banggai, Sulawesi Tengah (Saputro, G.B. \& Isa N.E.)

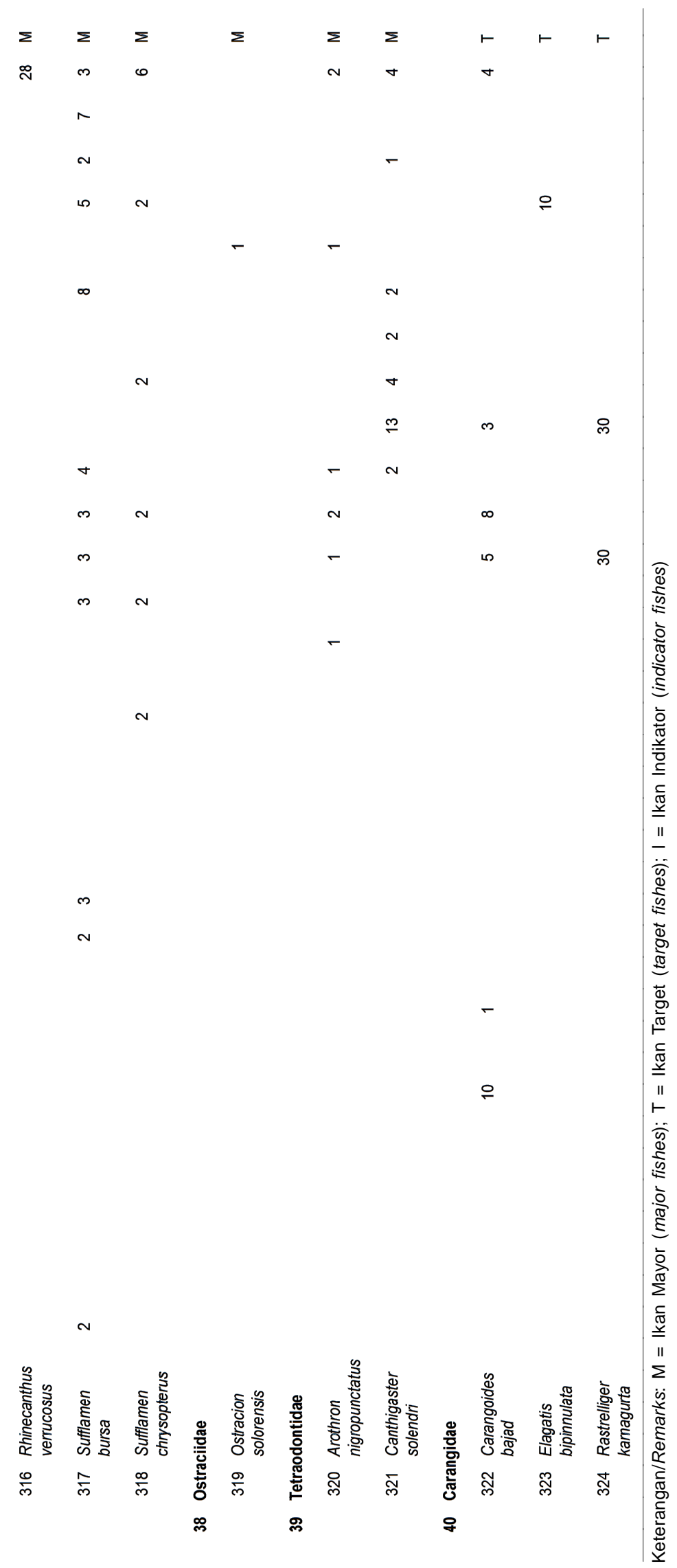

